\title{
Sentencia del Tribunal Constitucional recaida sobre el Proyecto de ley que crea la unidad de análisis financiero y modifica el Código Penal en materia de lavado y blanqueo de activos (rol 389)
}

Doctrina:

- La dignidad humana consagrada en el artículo $1^{\circ}$ inciso 1 de la Constitución es el principio capital consistente en la cualidad del ser humano que lo hace acreedor siempre a un trato de respeto, porque ella es la fuente de los derechos esenciales y de las garantías destinadas a obtener que sean resguardados.

- Es inconstitucional la habilitación irrestricta que se confiere al órgano administrativo para recabar, con cualidad imperativa, toda clase de antecedentes, sin que aparezca limitación alguna.

- El artículo 19 No 3 inciso 1 consagra el principio general que impone al legislador la obligación de dictar las normas que permitan a todos tener la oportunidad de defenderse de los cargos que la autoridad le formule.

Normas invocadas:

Constitución Política de la República de Chile:

- Artículo 1 inciso 1

- Artículo 19 numerales 3, 4, 5 y 15

- Artículo 38 inciso 1

- Artículo 74 incisos 1 y 2

- Artículo 87 inciso 1

- Artículo 88 inciso 1

Santiago, veintiocho de octubre de dos mil tres.

Vistos y considerando:

PRIMERO.- Que, por oficio No 4521, de 9 de septiembre de 2003, la Cámara de Diputados ha enviado el proyecto de ley, aprobado por el Congreso Nacional, que crea la unidad de análisis financiero y modifica el Código Penal en materia de lavado y blanqueo de activos, a fin de que este Tribunal, en conformidad a lo dispuesto en el artículo 82 ,
$N^{\circ} 1^{\circ}$, de la Constitución Política de la República, ejerza el control de constitucionalidad respecto del inciso tercero del artículo $1^{\circ}$; de la letra b), del inciso primero del artículo $2^{\circ}$; del artículo $8^{\circ}$, y del artículo 22, del mismo;

SEGUNDO.- Que, el artículo 82, No $1^{\circ}$, de la Constitución establece que es atribución de este Tribunal "Ejercer el control de la constitucionalidad de las leyes orgánicas constitucionales antes de su promulgación y de las leyes que interpreten algún precepto de la Constitución"; 


\section{Nomas de la constitucion que establecen el ambito de las leyes organicas constitucionales aplicables al contenido del proyecto}

I'ERC.ERO.- Que, el artículo 19, No 15, inciso quinto, de la Carta Fundamental, en lo pertinente, establece: "Los partidos políticos no podrán intervenir en actividades ajenas a las que Ies son propias ni tener privilegto alguno o monopolio de la participación ciudadana; la nómina de sus militantes sc rcgistrará en el servicio electoral del Estado, el que guardará reserva de la misma, la cual será accesible a los militantes del respectivo partido; su contabilidad deberá ser pública; las fuentes de su financiamiento no podrán provenir de dineros, bienes, donaciones, aportes ni créditos de origen extranjero; sus estatutos deberán contemplar las normas quc ascguren una efectiva democracia interna. Una ley orgánica constitucional regulará las demás materias que les conciernan y las sanciones que se aplicarán por el incumplimiento de sus preceptos, dentro de las cuales podrá considerar su disoluctón.";

CUARTO.. Que, el artículo 38, inciso primero, de la Ley Fundamental, dispone: "Una ley orgánica constitucional determinará la otganización básica de la Administración Pública, garantizaré la carrera funcionaria y los principios de carácrer técnico y profesional en que deba fundarse, y asegurará tanto la igualdad de oporunidades de ingreso a ella como la capacitación y el perfeccionatriento de sus integrantes."

QUINTO. Que, el artículo 74, incisos primero y segundo, de la Constitución, señalan: "Una ley otgánica constitucional determinará la organización y atribuciones $\mathrm{dc}$ los tribunales que fueren necesarios para la pronta y cumplida administración de justicia en todo el territorio de la República. La misma ley señalará las calidades que respectivamente deban tener los jueces y el númeto de afíos que deban haber ejercido la profesión de abogado las personas que fueren nombradas ministros de Core o jueces letrados. La ley orgánica constitucional relativa a la organización y atribuciones de los tribunales, sólo podrá ser modificada oyendo previamente a la Cone Suprema de conformidad a lo establecido en la ley orgánica constitucional respectiva."

SEXTO.- Que, el articulo 87, inciso primero, de la Carta Fundarmental, expresa: "Un onganismo autónotno con el nombre de Contraloria General de la República ejercerá el control de la legalidad de los actos de la Administración, fiscalizará el ingreso y la inversión de los fondos del Fisco, de las municipalidades y de los demás organismos y servicios que deteminen las leyes; examinará y juzgará las cuentas de las personas que tengan a su cargo bienes de esas entidades; Hevará la concabilidad general de la Nación, y desempeñará las demás funciones que le encomiende la ley orgánica constirucional respectiva."

A su vez, el artículo 88, inciso final, de la Ley Suprema, señala:

"En lo demás, la organización, el funcionamiento y las atribuciones de la Contratoría General de la República serán materia de una ley orgánica construcional.";

\section{Normas sometidas a control de constitucionalidad}

SEPTIMO.- Que, el artículo $1^{\circ}$, inciso tercero, del proyecto somecido señala: "El jefe superior del servicio tendrá el tículo de Director y se regirá por las normas contenidas en el Título VI de la ley No 19.882."

OCTAVO. Que, el precepto tanscrito en el considerando anteriot, al someter a] jefe superior del servicio que se crea a las disposiciones contempladas en el Tículo VI de la Ley $\mathrm{N}^{\text {t }}$ 19.882 , el cual contiene nortras que son propias de las leyes orgánicas constitucionales a que se refieren los artículos 38, inciso primero, 87, inciso primero, y 88, inciso final, y $19, N^{\circ} 15$, inciso quinto, de la Constitución Política, amplía su campo de aplicación, tazón por la cual las modifica, teniendo, en consecuencia, su misma naturaleza;

NOVENO.- Que, el articulo $2^{\circ}$, inciso primero, letra b), del proyecto remicido, indica:

"Artículo 20.- La Unidad de Análisis Financiero sólo tendrá las siguientes atribuciones y funciones, las que podrá desarollar $y$ ejercer en cualquier lugar del territorio nacionat:

“b) Solicitar los antecedentes que estime necesarios, sean informes, documentos o de otra naturaleza, a personas naturales y jurídicas, tas cuales estarán obligadas a proporcionarlos en el término que sc les fije. El otorgamiento de tales antecedentes será gratuito y libre de toda clase de derechos e impuestos. En el caso de que los antecedentes estén amparados por el secreto o reserva, cortesponderá autorizar esta solicitud al Presidente de la Corte de Apelaciones de Santiago. El Presidente resolverá dentro del plazo de veinticustro horas, sin audiencia ni intervención de terceros. La resolución que rechace la solicitud será someramente fundada, pudiendo la Unidad de Análisis Financiero apelar de ella. La apelación será conocida en cuenta y sin más trámite, por la sala de cuenta de la Corte de Apelaciones de Santiago, tan pronto se reciban los autos. La solicitud se tramitará en forma secreta y los antecedentes serán devueltos a la Unidad, para su archivo.

La obligación a que se refiere esta letra no regirá respecto de 
las personas que no están obligadas a declarar por razones de secreto, únicamente en lo que se refiera a éste, en los términos que señala el artículo 303; del Código Procesal Penal.";

DECIMO-- Que, las disposiciones contenidas en dicho precepro son, por una parte, propias de la ley orgánica cons. titucional a que alude el articulo 74, incisos primero y segundo, de la Carta Fundamental, puesto que conceden nuevas atributiones a los tribunales de justicia $y$, por otra, de la Ley No 18.575, Orgánica Constitucional de Bases Generales de la Administración del Estado, en atención a que difieren de aquellas comprendidas en los artictulos 10 , 13 y 14 , de dicho cuerpo legal, motivos por los cuales, tienen carácter orgánico constitucional;

DECIMOPRIMERO.- Que, el artículo $8^{\circ}$ del proyecto. establece:

"Sin perjuicio de la responsabilidad civil o penal que pudiera corresponderles, las personas naturales y juridicas sefaladas en el inciso primero del artículo $3^{\circ}$ que no cumplan con el deber de informar conremplado en ese artículo, o lo hagan contraviniendo lo instruido por la Unidad para tal efecto, y aquellas que infrinjan las obligaciones establecidas en los artículos $4^{\circ}$ y $5^{\circ}$ de esta ley, serán sancionadas por el Director de la Unidad con alguna de las siguientes sanciones:

\section{a) Amonestación;}

b) Multa a bencficio fiscal hasta por el monto de 5.000 unidades de fomento, que podrá aumentar hasta tres veces en caso de reiteración. Para la determinación del monto de la multa se considerarán, entre otras circunstancias, la gravedad $y$ las consecuencias del hecho u omisión y la capacidad económica del infractor. En el caso de que la infracción haya sido cometida por una persona juridica, la multa podrá ser impuesta a ella, a sus directores, administradores y a toda persona quie haya participado en el acto u omisión respectivo. Las multas deberán ser pagadas dentro del plazo de diez dfas, contado desde que se notifique la resolución respectiva.

La persona sancionada podrá deducir recurso de reposición antc la misma autoridad, dentro del plazo de cinco dias. En contra de la resolución que deniegue la reposición, podrá reclamar ante la Corte de Apelaciones respectiva dentro del plazo de diez dias, contado desde que se le notifique la nueva resolución. La Corte dará rraslado por seis dias a la Unjdad y, evacuado dicho trámite o acusada la respectiva rebeldia, dictará sentencia en el término de treinta días sin ulterior recurso. Estos plazos de dfas se entenderán de dias hábiles. La Unidad de Análisis Financiero comunicará la aplicación de estas sanciones a los organismos que fiscalicen a las entidades infractoras, si los hubiera.";

DECIMOSEGLNDO. Que, el articulo $8^{\circ} \mathrm{cs}$ propio de la ley orgánica consticucional a que se reftere el artículo 74 . incisos primero y segundo, de la Constinución, al otorgar nuevas facultades a los tribunales establecidos por la ley para administrar justicia;

DECIMOTERCERO.- Que, el artículo 22 del proyecto remitido para su control, dispone: "Agrégase, al final del inciso segundo del artículo 66 de ta Ley Orgánica Constitucional del Banco Central de Chile, contenida en el artículo primero de la ley $\mathrm{N}^{\circ} \mathrm{I} 8.840$, luego del punto aparte () , la siguiente oración: "lámpoco regirá la obligación de guardar reserva respecto de los anrecedentes que le soliciten la Unidad de Análisis Financiero o el Ministerio Público, tratándose delas operaciones sospechosas o de los delitos contemplados en la ley que crea la teferida Unidad.n.";

DECIMOCUARTO. Que, dicho precepto modifica una norma propia de la Ley No 18.840, Orgánica Constitucional del Banco Central de Chile, razón por la cual tiene su mismo carácter;

\section{Normas inconstitucionales}

\section{A}

DECIMOQUINT'O.- Que el articulo $2^{\circ}$ inciso primero letra b) del proyecto en examen preceptúa, literalmente, to siguiente: "La Unidad de Andilsis Financiero sólo tendrá las siguientes atribuciones y funciones, las que podrá desarrollar y sercer en cualquier lugar del territorio nacional:

\section{(...)}

b) Solicitar los antecedentes que estine necesarios, sean informes, documentos o de otra naturaleza a personas naturales y juridicas, las cuales estarán obligadas a proporcionarios en el término que se les fije. El otorgamiento de tales antecedentes será gratuito y libre de toda clase de derechos e impuestos. En el caso de que los antecedentes estén amparados por el secreto o reserva, corresponderá autorizar esta solicitud al Presidente de la Corte de Apelaciones de Santiago. El Presidente tesolverá dentro del plazo de veinticuatro horas, sin audiencia ni intervención de tetceros. La resolución que rechace la solicitud será someramente fundada, pudiendo ta Unidad de Análisis Financiero apelar de ella. La apelación será conocida en cuenta y sin más trámite, por la sala de cuenta de la Corte de Apelaciones de Santrago, tan pronto se reciban los autos. La solicitud se tramitará en forma secreta y los antecedentes serán devuettos a la Unidad, para su archivo. La obligación a que se refiere esta 
letra no regirá respecto de las personas que no están obligadas a declarar por razones de secreto, únicamente en lo que se refiera a éste, en los términos que seŕała el arículo 303 del Código Procesal Penal.";

DECIMOSEXTO.- Que procede analizar el mérito constírucional de la disposición del proyecto insertada en el considerando precedente, para lo cual resulta menester, con antelación, transcribir y fijar el sentido de las normas fundamentales correspondientes;

DECIMOSEPTIMO.- Que en tal orden de ideas cahe recordar, primesamente, por ser base del sistema institucional imperante en Chile, el articulo $l^{o}$ inciso primero de la Constitución, el cual dispone que "Las personas nacen libres e iguales en dignidad y derechos." Pues bien, la dignidad a la cual se alude en aquel principio capital de nuestro Código Supremo es la cualidad del ser humano que lo hace acreedor siempre a uл trato de respeto, porque ella es la fuente de los derechos csenciales y de las garantías destinadas a obrener que sеaл resguardados;

DECIMOCTAVO.- Que, además y como consectuencia de lo recién expuesto, la Carta Fundamental asegura a todas las personas, sin distinción ni exclusión alguna, en su articulo $19 N^{\circ} 4$ inciso primero, "El tespeto y protección a ta vida privada y pública y a la honra de la persona y de su familia." En tal sentido considera esta Magistracura necesario realzar la relación sustancial, clara y directa, que existe enure la dignidad de la persona, por una parte, $y$ su proyección inmediata en la vida privada de ella y de su familia, por otra, circunstancia que vuelve indispensable caurelar, mediante el respeto $y$ la protección debidas, ese ámbito reservado de la vida, en el cual no es lícito penetrar sin el consentimiento del afectado, de un lado, o por decisión de la autoridad fundada en la ley que hubicre sido dictada con sujeción a la Constitución, de otro;

DECIMONOVENO.- Que se asegura, asimismo y con idéntica amplitud, en el numeral 5 de aquel articulo 19, "La inviolabilidad del hogar y de toda forma de comunicación privada", puntualizándose que las comunicaciones y documentos privados pueden interceptarse, abrirse o registrarse en los casos y formas determinados por la ley. Nuevamente, estima esta Magistratura oportuno destacat el ligamen que existe entre la dignidad de la persona y el ejercicio de este detecho esencial, pues la inviolabilidad de las comuricaciones privadas debe ser considerada una extensión, lógica e inevitable, sobre todo en la vida moderna, del carácter personalisimo o reservado que tienen ellas como base de la libertad individual y su proyección en los más diversos aspectos de la convivencia:
VIGESIMO.- Que la privacidad, en los variados rubros descritos, integra los derechos personalísimos o del patrimonio moral de cada individuo, los cuales emanan de la dignidad personal, como se ha dicho, $y$ son, por su cualidad de intimos de cada sujeto, los más cercanos o próximos a esta característica, única y distintiva, del ser humano. Por tal razón, ellos merecen reconocimiento y protección excepcionalmente categóricos tanto por la ley, como por los actos de autoridad $y$ las conductas de particulares o las estipulaciones celebradas entre éstos;

VIGESIMOPRIMERO. - Que el respeto y protección de la dignidad y de los derechos a la privacidad de la vida y de las comunicaciones, son base esencial del desarrollo libre de la personalidad de cada sujeto, así como de su manifestación en la comunidad a través de los grupos intermedios autónomos con que se estructura la sociedad. En ligamen con to que viene de ser expucsto, menester resulta recordar que tal autonomía es también sustento del sistema de instituciones vigente en nuestro país, debiendo a su respecto cumplirse la exigencia de respeto, especialmente cuidadoso, que se ha destacado ya con relación a la dignidad de la persona humana;

VIGESIMOSEGUNDO.- Que el ejercicio del derecho a la vida privada y a la protección de las comunicaciones de igual naturaleza no es, obviamente, de sentido y alcance absoluto, debiendo ser reconocido, por consigutente, que el legislador, dentro de los línites y para las finalidades previscas en $\mathrm{l}_{2}$ Constitución, especialmente en los preceptos fundamentales de ella ya transcritos en la presente sentencra, está habilitado en orden a dictar las normas que regulen su ejercicio para que sea legítimo. Sin embargo, idénticamente claro es para esta Magistratura que la ley no puede, sobre la hase de la habilitación constitucional recién destacada, afectar en su esencia el contenido sustancial de ese derecho, como tampoco imponerie condiciones o requisitos que impidan su libre ejercicio ni privarlo de la debida tutela jurídica; VIGESIMOTERCERO-- Que lo razonado en el considerando precedente se aplica, con semejante vigor, al derecho asegurado en el artículo 19 No 5 de la Constitución, pues la competencia otorgada al legislador en virud de tal disposición, concerniente a que las comunicaciones privadas pueden ser interceptadas, registradas o abiertas en los casos y en la forma que señale la ley, debe entenderse que no permite, a través de las normas pertinentes, afectar ni lesionar el núcleo esencial del derecho fundamental asegurado; VIGESIMOCUARTO.- Que, a la luz de las consideraciones expuestas, pasa ahota el Tribunal a pronunciarse sobure el mérito constitucional del articulo $2^{\circ}$ inciso primero letra b) del proyecto; 
VIGESIMOQUINTO.- Que, en tal orden de ideas, csta Magistratura considera necesario detenerse en los rasgos matrices de dicho precepto para dejar de manificsto sus caracteristicas principales. En ese sencido, $y$ desde luego, se observa la habilitación irrestricta que el inciso primero de la letra b) otorga al órgano adninistrativo correspondiente para recabar, con cualidad imperativa, toda clase de antecedentes, sin que aparezca liminación alguna que constrifia tal competencia al ámbito estricto y acotado en que podría hallas justificación.

Es más, dicha habilitación se confiere sin trazar en la ley las pautas o parámetros, objetivos y controlables, que garanticen que el órgano administrativo pertinente se ha circunscrito a ellos, asumiendo la responsabilidad consecuente cuardo los ha transgredido.

Los razonamientos anteriores resultan también aplicables a in antecedentes secretos o reservados a que se refiere el inciso tercero de la letra b) en exatnen, puesto que para requerirlos, basta sólo que lo autorice el Presidente de la Corte de Apelaciones de Santiago, sin audiencia del afectado ni de terceros, tramitándose ha solicitud de la autoridad administrativa en forma secreta, $y$ debiendo aquel magistrado devolver los antecedentes del caso a ese órgano administrativo, lo que resulta absolutamente insuficiente;

VIGESIMOSEXTO,- Que, por consiguiente, Ia disposición en examen merece ser calificada como discrecional, es decir, abierta, por la indeterminación que contiene, con respecto a las decisiones que el Direcror del órgano pettinente juzgue necesario llevar a la práctica, circunstancia que reviste gravedad singular tratándose de la dignidad y de los derechos esenciales ya comentados;

VIGESIMOSEPTIMO.- Que se halla asi demostrado que la dignidad de la persona y sus derechos a la vida privada y a la rescrva de las comunicaciones de tgual naturaleza, que fluyen de aquella, quedan en situación de ser afectados en su esencia por la normativa del proyecto examinado, sin que esta iniciativa contcmple los resguardos y controles heterónomos indispensables, sobre todo los de naturaleza judicial, que eviten o recrifiquen tal eventualidad, motivos por los cuales debe ser declarada la inconstitucionalidad del artículo $2^{\circ}$ inciso primero letra b) del proyecto.

\section{B}

VIGESIMOCTAVO.- Que, por otra parte, la Constitución asegura a todas las personas en su artículo 19 No 3 inciso primero, "La igual protección de la ley en el ejetcicio de sus derechos.";
VIGESIMONOVENO.- Que, en dicho precepto se consagra el principio general que impone al legistador la obligación de dictar las normas que permitan a todos quienes sean, o puedan ser afectados en el legítimo ejercicio de sus derechos fundanentales, tener la oportunidad de defendesse de los cargos que la autoridad le formule. Se desprende de to anterior, que la voluntad del Podet Constituyente es que la ley ha de contemplar las disposictones que resguar. den el goce efectivo y seguro de tales derechos;

TRIGESIMO-- Que, a su vez, el articulo is numero tercero inciso segundo de la Carta Fundamental, declara que "Toda persona tiene derecho a defensa jurídica en la forma que la ley señale y ninguna autoridad o individuo podrá impedir, restringir o perturbar la debida intervención del letrado si hubiere sido requerida..".;

TRIGESIMOPRIMERO.- Que el derecho que esta última norma consagra se encuentra en relación, sustancial y directa, con aquel que contempla el inciso primero del mistho precepto, precisando el sentido y alcance de la protección que el legislador debe prestar al ejercicio de los derechos de roda persona, refiriéndola específicanente a la defensa juridica de ellos ante la autoridad que corresponda;

TRIGESIMOSEGUNDO.- Que al respecto es necesario examinar las nomias del proyecto remitido que se transcriben a continuación:

1. Articulo $2^{\circ}$, inciso primero, letra j), que comprende entre las atribuciones de la Unidad de Análisis Financiero la siguiente: "Imponer las sanciones administrativas que establece la presente lcy".

2. Artículo $8^{\circ}$, que dispone: "Sin perjusicio de la responsabilidad civil o penal que pudicra corresponderles, las personas naturales y juridicas serialadas en el inciso primero del articulo $3^{\circ}$ gue no cumplan con el deber de informar consemplado en ese articula, olo hagan contraviniendo ho instruido por la Unidad pana tal efecto, y aquellas que infrinjan las obligaciones establecidas en los articulos $4^{\circ} \mathrm{y}$ $5^{\circ}$ de esta ly, serán sancionadas por el Director de la Unidad con alguna de las siguientes sanciones:

a) Amonestación;

b) Multa a beneficio fiscal hasta por el monto de 5.000 unidades de fomenro, que podrá aumentar hasta tres veces en caso de reiteración.

Para la determinación del monto de la multa se considerarán, entre otras circunstancias, la gravedad y las consecuen cias del hecho ti omisión y la capacidad económica del infractor. En el caso de que la infracción haya sido cometida por una persona jurídica, la mulra padrá ser impuesta a ella, 
a sus directores, adrinistradores y a toda persona que haya participado en el acto u omisión respectivo. Las multas deberán set pagadas dentro del plazo de diez dias, contado desde que se notifique la resolución respectiva. La persona sancionada podrá deducir recurso de reposición ante la misma autoridad, dentro del plazo de cinco dias. En contra de la resolución que deniegue la reposición, podrá reclamar ante la Corte de Apelaciones respectiva dentro del plazo de diez días, contado desde que se le notifrque la nueva resolu. ción. La Corte dará traslado por seis dias a la Unidad y, evacuado dicho trámite o acusada la tespectiva rebeldia, dictará sentencia en el término de treinta días sin ulterior recurso. Estos plazos de días se entenderán de días hábiles. La Unidad de Análisis Financiero comunicará la aplicación de estas sanciones a los organismos que fiscalicen a las entidades infractoras, si los hubiera.";

TRIGESIMOTERCERO.- Que del análisis de las disposjciones transcritas en el considcrando anterior, se desprende que to se contempla en ellas procediniento alguno que permita al afectado una adecuada defensa de sus derechos, en sede administrativa, en fortna previa a la imposición de alguna de las sanciones que el artículo $8^{\circ}$ establece;

TRIGESIMOCUARTO.- Que, resuita evidente, por lo tanto, que el Legislador ha dejado de cumplir con la obligación que el Poder Constituyente le impone, de dictar las normas cendientes a asegurar la protección y defensa jurídica de los derechos fundamentales de quienes se encuentren comprendidos en las siruaciones que, de actuetdo con lo dispuesto en el articulo $8^{\circ}$, determinan la imposición de una sanción. Más aún, elio puede tmer como consecuencia el lesionar el ejercicio de los derechos comprometidos, circunstancia que pugna con las garantias que, en los incisos primero y segundo del numeral tercero del artículo 19 , la Carta Fundamental consagra para resguardarlos;

TRIGESIMOQUINTTO.- Que, atendido lo que se termina de señalar, debe concluirse que las nomas comprendidas en el articulo $8^{\circ}$ del proyecto remitido $y$, consecuencialmente en el artículo $2^{\circ}$ inciso primero letra j) def mismo, vutneran lo dispuesto en el articulo 19 No $3^{\circ}$ incisos primero y segundo de la Constitución;

TRIGESIMOSEXTO.- Que, no obsta a lo anteriormente expuesto, el que el propio arfículo $8^{\circ}$, $\mathrm{cn}$ su inciso tercero, seriale que el afectado puede deducit recurso de reposición ante el Director de la Unidad y que, en caso que dicho recurso sea denegado, tiene la facultad de reclamar ante la Corte de Apelaciones respectiva.

Elto no altera la inconstitucionalidad de las nomas en estudio, en atención a que no subsana el hecho de que antes de la aplicación de la sanción por la autoridad administrativa, el afectado carece del derecho a defensa jurídica que el articulo $19, \mathrm{~N}^{\circ} 3^{\circ}$, inciso segundo, en armonía con el inciso primero del mismo precepto de la Carta Fundamental, lo reconocen. Este derecho a defenderse debe poder ejercerse, en plenitud, en todos y cada uno de los estadios en que se desarrollia el procedimiento, a través de los cuales se pueden ir consolidando situaciones jurídicas muchas veces irreversibles. A lo que es necesario agregar, que resulta evidente que el poder recurrir ante la Corte de Apelaciones respectiva no es suficiente para entender que, por esa circunstancia, se ha convalidado una situación administrativa constirucionalmente objetable.

TRIGESIMOSEP'11MO.- Que, por lo tanto, los preceptos contenidos en el artículo $2^{\circ}$ inciso primero letra jj), $y$ en el artículo $8^{\circ}$ del proyecto remitido son inconstitucionales $y$ asi debe declararse;

TRIGESIMOCTAVO, Que, a mayor abundamiento, se hace presente que en sentencia de 17 de jurito de 2003 dictada en relación con el proyecto de ley sobre transparencra, límite y control del gasto electoral, autos Rol No 376 este Tribunal declaró la inconstitucionalidad de determinadas normas establecidas en él, por las mismas razones contenidas en los considerandos precedentes.

\section{Inconstitucionalidades derivadas}

TRIGESIMONOVENO.- Que, de acuerdo a lo resuelto por esta Magistratura en la sentencia de 28 de julio de 1998 . autos Rol No 276, declarado por el Tribunal que un determinado articulo de un proyecto es inconstitucional, igual mente lo son aquellas normas dei mismo que se encuentren tan ligadas con aquél, que por si solas carezcan de sentido, se tornen inoperantes o, dada la intina conexión entse si, se pueda presumir razonablemente que los órganos colegisladores no las hubieren aprobado; CUADRAGESIMO.- Que en la situación jurídica anteriormente precisada, están las disposiciones del texto en examen que hacen referencia al articulo $2^{\circ}$ letra b) que se declarará inconstitucional, por cuanto ellas, por si mismas, sin la debida correlación con la norma aludida, no tienen significación alguna, es decit, como lo expresa la sentencia aludida, "carecen de sentido", o se apartan de la voluntad legislativa con la cual fueron aprobadas, como acontece con la parte primera de la letra g) del artículo $2^{\circ}$, después de la inconstitucionalidad que afectará a su oración fina;

CUADRAGESIMOPRIMERO.- Que en la condición sefralada en el considerando precedente se encuentran los preceptos del proyecto en estudio que se indican a continuación: 
a) la letra g) del inciso primero del articulo $2^{\circ}$ que señala: "g) Acceder sin limitación a las bases de datos de los orgonismos püblicos en la forma en que se contenga con el jefe superior de la entidad respectiva. Si éste invoca el secreto o La reserva, se procederá conforme a lo dispuesto en d texcer partafo de la (etra b) del presente articulo.";

b) la frase del articulo $6^{\circ}$ que prescribe: " 2 , inciso primero, tetra b) $y^{n}, y$ c) la locución del artículo $7^{\circ}$ que dispone: "y la entrega de antecedentes folsos, referidos en la letra b) del inciso primero del articulo $2^{\circ}$ de esta ley o la destrucción w ocultamiento de éstos".

Por tanto, todos ellos procede declararios inconstitucionales y así se resolverá.

\section{Cumplimiento de quorum, informe y declaracion final}

CUADRAGESIMOSEGUNDO.- Que, consta de autos, que los preceptos a que se ha hecho referencia han sido aprobados en ambas Cámaras del Congreso Nacional con las mayorias requeridas por el inciso segundo del artículo 63 de la Constitución, y que sobre ellos no se ha suscitado cuestión de constitucionalidad;

CUADRAGESIMOTERCERO.- Que, asimismo, consta de autos que se ha dado cumplimiento al artículo 74, inciso segundo, de la Constitución, de acuerdo al tenor del oficio No 1562 , de $1^{\circ}$ de julio de 2002, que la Corte Suprema dirigiers a la Cámara de Diputados, informando sobte el proyecto remitido;

CUADRAGESIMOCUARTO.- Los Ministros que suscriben esta sentencia estiman necesario, frente a la prevención del Ministro Juan Agustín Figueroa, dejar testimonio en el fallo, de lo dispuesto en los dos incisos finales del articulo $2^{\circ}$ del proyecro en examen. Expresan, textualmente, dichos preceptos:

“Bajo ningún respecto la Unidad de Análisis Financiero podrá ejercer competencias propias del Ministerio Público o de los Tribunales de Jusricia. Asimismo, sólo podrá utilizar la información que reciba para los propósitos establecidos en esta ley, no pudiendo en caso alguno darla a conocer o entregarla a organismos o servicios distintos del Ministerio Público."

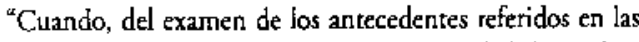
letras que anteceden, el Director de la Lnidad de Arálisis Financiero estime que aparecen indicios de que se ha cometido alguno de los delitos a que se refiere el artículo 20 de esta ley, deberá disponer su inmediata remisión al Ministerio Público. Asimismo, el Ministerio Público podrá reque- rit a la Unidad el envío de los antecedentes que estén en $\$ 4$ poder $y$ que sean necesarios para las investigaciones de lavado de activos que practique, se hayan iniciado de oficio, por dertuncia o por querella, cualquiera sea la fase en que ellas se encuentren."

Y, VISTO, lo prescrito en los articulos 10 , inciso primero, $19, \mathrm{No}_{\text {s. }} 3^{\circ}$, incisos primeto y segundo, $4^{\circ}$, inciso primero, 50,15 , inciso quinto, $y 26 ; 38$, inciso primero, 63 , inciso segundo, 74, inciso primero y segundo, 82 , No $1^{\circ}$ e inciso eercero, 87, inciso primero, 88, inciso final, y 97 de la Constitución Política de la República, y lo dispuesto en los artículos 34 al 37 de la Lcy No 17.997, de 19 de mayo de 1981 ,

\section{Se declara:}

1. Que los preceptos comprendidos en los artículos lu, inciso tercero, y 22, del proyecto remitido, son constitucionales.

2. Que los preceptos contemplados en los artículos $2{ }^{\circ}$, inciso primero, letra b), y $8^{n}$, del proyecto remitido son inconstitucionales y deben eliminarse de su texto.

3. Que igualmente, tas siguientes disposiciones deI proyecto son inconstitucionales y deben eliminarse de su texto: a) la letra g) del inciso primero del artículo $2^{\circ}$ que señala: "g) Acceder sin limitación a las bases de datos de los organismos puiblicos en la forma en que se convenga con al jefe superior de La entidad respectiva. Si éste invoca el secreto o la reserva, se procederá conforme a lo dispuesto en al uercer párafo de la letra b) del presente articulo. ${ }^{n}$; b) la letra j) del inciso primeto del artículo $2^{\circ}$ que indica: "Imponer las sanciones administrativas que establece la presente $k y^{\prime}$. c) la frase del articulo $6^{\circ}$ que prescribe: " 20 , inciso primero, ketra b) y", y d) la oración del articulo $7^{\circ}$ que dispone: "y la entrega de anteceden. tes falsos, referidos en la letra b) del inciso primero del articulo $2^{\circ}$ de esta ley, o la destrucción $\mathrm{n}$ ocultamiento de éstos".

Se previene que el Presidente serior Juan Colombo Campbell y los Ministros setiores Hernán Alvarez García y Marcos Libedinsky Tschorne no suscriben los razonamientos de las partes finales de los considerandos vigesimoquinto $y$ trigesimosexto de la sentencia, por las siguientes tazones:

10) Que en relación al considerando vigesimoquinto, parte final, que ta sentencia formula como sustento a la inconstitucionalidad que se declara, se refiere a la faculrad que el proyecto otorga a la Unidad de Análisis Financiero, para recabar información preventiva de antecedentes amparados por el secrcto o reserva, previa autorización del Presidente de la Corte de Apelaciones de Santiago, para destinarlos posteriormente si hubiere mérito, al Ministerio Pú- 
blico y, asi finalmente, la justicia pueda establecer la comisión de los delitos contemplados en este proyecto de ley. La pare pertinente del considerando seńala: «Los razonamierttos anteriores resultan también aplicables a los anteceden. tes secretos o reservados a que se refierc cl inciso tercero de la letra b) en examen, ptuesto que para requerirlos, basta sólo que lo autorice el Presidente de la Corte de Apelaciones de Santiago, sin audiencia del afectado ni de terceros, tramitándose la solicitud de la autoridad administrativa en forma secreta, $y$ debiendo aquel magistrado devolver los antecedentes del caso a ese órgano administrativo. lo que resulta absoluramentc insuficiente;".

$\left.2^{\circ}\right)$ Que, en relación a este argumento los previnientes tienen en cuenta que el Presidente de la Corte de Apelaciones de Santiago es un tribunal unipersonal reconocido por los articulos 50 y 5 I del Código Orgánico de Tribunales, al que el legisiador orgánico, en conformidad al artículo $74 \mathrm{dc}$ iz Constitución, puede, y en esta oportunidad le asigna, una nueva competencia.

30) Que, igualmente tienen en cuenta que cl legislador en los procedimientos nacionales, tanto en el orden civil como penal, aplicando principios informadores vastamente conocidos, ha adoptado el principio de ha unilateralidad en casos excepcionales y cautelares y como una manera de asegurar la eficacia de determinadas actuaciones o resoluciones futuras y decisorias del ámbito jurisdiccional, el que puede usar sin violentar ningún precepto de la Constirución.

40) Que, en esta oportunidad los previnientes reiteran la posición contenida en Rol N 349 , en orden a discrepar de la mayoría. En tal disidencia se expresó por los jueces discrepantes Colombo y Alvarez, que aconcordamos plenamente en ello cuando estamos en presencia de un proceso destinado a resolver una controversia, pero no en tanto se recurra a la jurisdicción para recabar un antecedente» como es el caso previsto por el artículo $2^{\circ}$, letra b) inciso tetcero del proyecto en examen.

En otros téminos, la bilateralidad es un presupuesto del proceso propiamente tal, pero no puedc negársele al legislador la facultad de emplear el de la unilarcralidad cuando el mérito de la norma así lo precise, criterio que podemos enconrrar aplicado en el juicio ejecutivo, en las medidas prejudiciales $y$ en diversas disposiciones cautelares del nuevo Código Procesal Penal.

50) Que en relación a la parte final del considerando trigesimosexto, que expresa: $\mathrm{k}$ lo que es necesario agregar, que resulta evidente que el poder recurrir ante la Corte de Apelaciones respectiva no es suficiente para entender que, por esa circunstancia, se ha convalidado una situación ad- ministrativa constitucionalmente objetable. ${ }^{n}$, los previnientes tienen al tespecto presente que a la Corte de Apelaciones respectiva, como tribunal ordinario que es, también se le ha conferido competencia jurisdiccional para resolver asuntos contenciosos derivados del ejercicio de la función administrativa.

6o) Que el teferido resorte procesal lo coloca bajo la protección jurisdiccional y, por to tanto, no comparten el pensamiento de la mayorfa en cuanto estima que resulta evidente que el poder recurrir ante dicho tribunal es insuficiente para convalidar una situación administrativa constitucionaimente objetable.

70) Que, a mayor abundamiento, la persona sancionada podrá deducit previamente recurso de reposición, y en contra de la resolución que la deniegue apelación, cuya competencia es la que se declara insufficiente como protección constitucional por el considerando referido. En este caso la tramitación de los recursos se rigen en todo por el principio de la bilateralidad.

80) Que, finalmente, debe tenerse en cuenta que se trata de obtener antecedentes destinados a prevenir e impedir la utilización del sistema financiero y de otros sectores de la actividad económica, para la posible comisión de algunos de los delitos descritos en el artículo 20 de este proyecto de ley. Si de ellos, como se dijo, surgiere alguna sospecha o indicio que amerite configurar alguno de los delitos antes mencionados, el servicio deberí disponer su inmediata remisión al Ministerio Público, al tenor de lo dispuesto en la parte final del artículo $2^{\circ}$.

Se previene que el Ministro señor Juan Agustín Figueroa Yávar fue de parecer de entrat, de oficio, a examinar las demás atribuciones que el articulo $2^{\circ}$ del proyecto confiere a ta Unidad que se estaruye, $y$ - consectuencialmente- a las normas que la crean. Todo ello por las siguientes razones:

10. Que la preceptiva a la que recién se ha hecho referencia, se encuentra indisolublemente vinculada a aquellas narmas sometidas a la fiscalización de esta Magistratura. Ello resulta patente porque todas ellas, de manera conjugada, pretenden cumplir las finalidades que el legislador expresa haber tenido en vista $y$, de esta manera, se refieren a una mísma materia y persiguen un mismo objetivo. El criterio de extender la competencia en la forma sefialada, ha sido reiteradamente mantenido por este Tribunal.

20. Que el examen de constitucionalidad que se postula en esta caso, se hace necesario potque se refiere a materias particularmente sensibles, como son los derechos y deberes constitucionales que se ligan a la creación e indagación de ilícitos penales. Ello toca al núcleo mismo de aquelios que 
miran a la libertad individual y la seguridad personal, a más de varios otros, algunos de los cuales han sido expresamente mencionados en este fallo.

$3^{\circ}$. Que miradas en conjunto las potestades que se entregan al órgaro administrativo que se crea, no obstante lo que se declara en contrario en el inciso segundo del artículo $2^{\circ}$ de la iniciativa, lo cierto es que ellas importan encomendarle una labor de investigación de ilícitos perales, lo que nuestra Carta ha enrregado, de manera exclusiva y excluyente, al Ministerio Público, todo ello al tenor de lo prescrito en el articulo $80 \mathrm{~A}$ de aquel cuerpo, en concordancia con lo establecido en la Ley No 19.640. En efecto, la finalidad precisa que se concede al organo administrativo al que se le da vida, es prevenir $e$ impedir ciertos y determinados delitos. Pero estos últimos, si bien se penan autónotnamente, son técnicamente la fase de agotamiento de otros a los cuales también se hace remisión.

De esta manera, el prevenir la ocurrencia de esta última etapa del "iter criminis", importa necesariamente indagar la comisión de los que la preceden, lo que cae de lleno en la actividad propia del Ministerio Público.

40. Que en un anterior pronunciamiento este Tribunal ha aceptado que la autoridad administrativa efectúe una labor de recopilación de antecedcntes, aún cuando ellos se refreran a un posible ilícito penal. Pero como se desprende del sentido natural del verbo, su alcance es el de juntar lo que orros han producido, to que es muy distinto a una labor indagatoria activa, como es - conforme al proyecto - la de requerir declaraciones obligatorias, de todo tipo, a un gran conjunto de personas, la de ordenar exámenes periciales, la de estar revestida de potestades normativas y la de coordjnar información con entes similares extranjeros. Entregar tal cúmulo de atribuciones a un ente administrativo tesulta asistemático con la creación del Ministerio Público y el conjunto de regulaciones a las que éste se encuentra sometido. Su misión está estrictamente enmarcada por un conjunto de garantías para el indagado, lo que contrasta con las muy febics salvaguardas que contempla el proyecto, lo que hacia necesatio un especifico prontunciamiento sobre todas las facuitades que se conceden a la Unidad de Análisis Financiero y a la creación misma de aquel ente investigador.

50. Que finalmente este previniente deplora que no se hayan consultado también varias otras disposiciones contenidas en el Título II del proyecto, que miran a normas punitivas substanciales y procesal penales, no directamente vinculadas a las sometidas a nuestro conocimiento, pero cuyo análisis de constitucionalidad podría taaber sido particularmente trascendente.
Aprobada la inconstitucionalidad del artículo $8^{\circ} \mathrm{del}$ proyecto, con el voro en contra del Presidente señor Juan Colombo Camphell, por cuanro estima que sólo debe declararse inconstitucional en cuanto contempla la facultad de imponer las sanciones administrativas que establece el proyccto, cn el caso de infracción al articulo $3^{\circ}, y$ mantenerse por las infracciones a los articulos $4^{\circ}$ y $5^{\circ}$, por los siguiences fundamentos:

10. Que en mérito de lo considerado en la sentencia, con la salvedad de la prevención, es de opinión que en el artículo $8^{\circ}$ debiera suprimirse por inconstitucional solamente la siguiente frase *las personas naturales y jurídicas señaladas en el inciso primero del articulo $3^{\circ}$ que no cumplan con el deber de informat contemplado en ese articulo, o lo hagan contraviniendo to instruido por la Unidad para tal efecro $y^{\star}$, manteniéndose el resto de la disposición.

$2^{\circ}$. Que sustenta tal posición en que los artículos $4^{\circ}$ y $5^{\circ}$ establecen exigencias que forman parte del mérito del proyecto que crea la Unidad de Análisis Financiero, que son objetivas y que están sometidas al control jurisdiccional.

30. Que tiene adenás presente, que la exigencia prevista en d artículo $4^{\circ}$ pasa por una declamaión previa del Scrvicio Nacional de Aduanas, y que el $5^{\circ}$ sólo exige que se mantengan registros por operaciones en dinero superiores a 450 UF o su equivalente en otras monedas, por lo cual ambas situaciones son diferentes a la petición de antecedentes a los sujetos mencionados en $\mathrm{cl}$ artículo $3^{\circ}$ del proyecto. $4^{\circ}$. Que finalmente se reitera lo expresado en la prevención, en cuanto a que ambas situaciones son reclamables administrativamente y susceptibles de revisión jurisdiccional.

Redactaron la sentencia los Ministros que la suscriben $y$ las prevenciones y disidencia sus autores.

Devuélvase el proyecto a la Cámara de Diputados, rubricado en cada una de sus hojas por el Secretario del Tribunal, oficiándose.

Registrese, déjese fotocopia del proyecto $y$ archivese.

Rol No 389 .

Pronunciada por el Excmo. Tribunal Constitucional, integrado por su Presidente don Juan Colombo Campbell, y los Ministros señores Eugenio Valenzuela Somarriva, Hemán Alvarez Garcia, ]uan Agustín Figueroa Yávar, Marcos Libedinsky Tschorne, Eleodoro Ortíz Sepúlveda y José Luis Cea Egana.

Autoriza el Secretario del Tribunal Constitucional, don Rafael Larrain Cruz. 



\section{Comentario a la Sentencia del}

\section{Tribunal Constitucional Sobre el Proyecto de Ley que Crea la Unidad de Análisis Financiero**}

Comentario de Miguel Ángel Fernández González

Profesor de Derecho Constitucional

\section{Introducción}

En la idea, ya tradicional en esta Revista, en orden a incluir comentarios de jurisprudencia, resulta interesante examinar el pronunciamiento evacuado por el Tribunal Constitucional cuando en conformidad al artículo $82^{\circ} \mathrm{N}^{\circ} 1^{\circ}$ de la Carta Fundamental, debió ejercer el control de constitucionalidad respecto del proyecto de ley que creó la Unidad de Análisis Financiero y modificó el Código Penal en materia de Lavado y blanques de activos:

Es de interés cxaminar dicha sentencia, pronunciada el 28 de octubre de 2003, bajo el Rol $\Lambda^{\text {Tc }} 389$, por cuanto en ella el Tribunal Constitucional defme, por primeta vez, el concepto de dignidad y explica su relación con los derechos fundamentales; sc precisa el amplio alcance del derecho a la defensa; $y$, finatmente, a propósito de la prevención del Ministro Figueroa Yávar, se abre paso a la feble constitucionalidad en que queda la Unidad de Análsis Financiero de frente a las funciones que la Carta Fundamental ha atribuido, con rango exclusivo, al Ministerio Público, en el contexto del Nuevo Proceso Penal.

\section{La Dignidad Humana}

A propósito del examen que va a llevar a cabo el Tribunal Constitucional respecto de la atribución que se le encomendaba, en el articulo $2^{\circ}$ inciso $1^{\circ}$ del proyecto, a la Unidad de Análisis Financiero, en cuanto a solicitar, en secreto, los antecedentes que estime necesarios, sear informes, documentos o de ot ra naturaleza, a personas naturales y juridicas, aquella Alta Magistratura va a sostener, en el considerando $16^{\circ}$ de la sentencia en comento, que resulta menester "con antelación. transcribir y fijar el sentido de las normas fundamentales correspondientes", refiriéndose con ello a que el asunto debe ser situado. por cierto, en relación con los derechos fundamentales alcanzados por aquella disposición, pero -aun antes- en la dignidad de las personas.

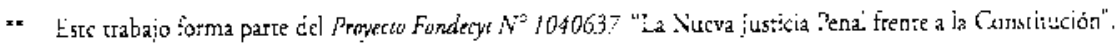

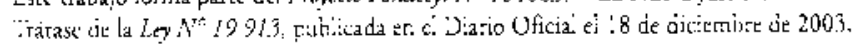




\section{Definición y Alcance}

El considerando $17^{\circ}$ de la sentencía señala que:

"...por ser base del sistema institucional imperante en Chile, el artículo $1^{o}$ inciso primero de la Constitución, el cual dispone que 'Las personas nacen libres e iguales en dignidad y derechos'. Pues bien, la dignidad a la cual se alude en aquel principio capital de nuestro Código Supremo es la cualidad del ser humano que lo hace acreedor siempre a un trato de respeto, porque ella es la fuente de los derechos esenciales $y$ de las garantias destinadas a obtener que sean resguardados".

Aparece así, por primera vez en nuestra Justicia Constitucional, definido el concepto de dignidad que emplea la Carta Fundamental, asignándosele un papel preponderante y, por lo mismo, de vastas consecuencias; ciertamente, la definición que adopta el Tribunal se sustenta en el sentido natural y obvio de la palabra dignidad ${ }^{2}$, pues ella no se encuentra definida en nuestro ordenamiento jurídico y en la escasa doctrina que la ha analizado:

"Antes y sobre los derechos públicos subjetivos mencionados y otros más, en la Constitución consta hoy proclamado el valor de la dignidad de la persona humana, nada menos que en el umbral, esto es, al comienzo del primero de sus artículos.

La dignidad humana se erige así en el valor sustentable de aquellos derechos inalienables, en la fuente o base de arranque de ellos y que debe ser tan respetada y promovida como estos...

Trátase de otro concepto iusnaturalista. Significa que toda persona humana, por ser tal y sin más exigencias, nace y ba de convivir con la cualidad de digno, o sea, de trascendente a la historia, sujeto libre e igual al prójimo, cuyo destino es realizar un proyecto de vida, con sello singular o propio.

El hombre resulta ser asi un depósito o cúmulo de valores supremos, con los cuales nace y los concreta durante la vida. Entre éstos se hallan los derechos públicos subjetivos o facultades que el ordenamiento jurídico le reconoce con carácter de inalienables, imprescriptibles e inviolables en todo momento, lugar y circunstancia... Pues bien, la dignidad es la fuente de esos atributos naturales" ${ }^{n}$.

Útil es advertir que, junto a la conceptualización de la dignidad como la cualidad del ser humano que lo hace acreedor, o sea, merecedor siempre -sin excepción de especie alguna- a un trato de respeto, es decir, considerado y deferente ${ }^{\dagger}$, se agrega la justificación de aquella cualidad, consistente, por una parte, en que la dignidad es la fuente de los derechos esenciales y, de otra, en que ella también es el origen de las garantias tendientes a resguardar aquellos derechos fundamentales.

Se comprende, entonces, las dimensiones cautelares, protectivas y promotoras de los derechos humanos a que puede llegarse por vía del respeto a la dignidad de la persona, en la interpretación y aplicación de la Constitución, particularmente, cuando se trata de confrontarla con la legislación comple-

2 Diccionario de la Real Arademia de La Lengua Española (Madrid, Ed. Espasa, 2001) p.

3 José Luis Cea Egañas I Derecho Constitucional Chileno (Santiago, Ediciones Universidad Catótica, 2001) pp. 102 y 178.

4 Diccionario citadio en supra nota 2, p. 1,32\%. 
mentaria, v. gr., en nexo con los derechos aludidos, pero también con otros de singular importancia, como la libertad de conciencia o la libertad personal, y los institutos inherentes al proceso penal, sobre todo considerando los fundamentos dogmáticos e históricos del valor de aquella dignidad:

"El artículo $1^{\circ}$ inciso $1^{\circ}$ de la Constitución seńala que las personas nacen libres e iguales en dignidad y en derechos, es decir, cada individuo de la especie humana, cualquiera sea su edad, sexo, estirpe o condicion, nace con dichos atributos o propiedades inherentes y no es el Estado, la sociedad organizada ni la Constitución quienes se los reconocen, pues es titular de ellos por el solo hecho de ser persona"s.

No puede olvidarse que el origen del precepto constitucional, contenido en el artículo $1^{\circ}$ inciso $1^{\circ} \mathrm{de}$ la Carta Fundarnental, se encuentra en su homónimo de la Declaración Universal de Derechos Humanos, al tenor del cual "todos los seres humanos nacen libres e iguales en dignidad y derechos y, dotados como están de razón y conciencia, deben comportarse fraternalmente los unos con los otros":

"La idea de persona concita hasta boy un grado de respeto y gerce un poderio de sentido, no necesariamente ligados a la profundidad y claridad con que se la comprende, sino, más bien, a algo que desde antiguo la rodea. Diríase de ella que es una palabra con carisma...

Es que la idea de persona es eminentemente cristiana y no parece posible desgajarla de ese tronco a la hora de comprender su dignidad. Es cierto que tomará un relieve propio a su paso por la filosofía práctica de Kant y contemporáneamente por la ética de Scheler -donde la persona es la sede de los valores- o en otras corrientes como el personalismo americano o la ideología de la revista Esprit, pero su fuerza originaria está esencialmente ligada a la primera formulación del pensamiento cristiano..."

En efecto, $y$ yendo a aquella fuente originaria tiene que decirse que:

"Los hombres de nuestro tiempo se hacen cada vez más conscientes de la dignidad de la persona humana, y aumenta el número de aquellos que exigen que los hombres en su actuación gocen y usen del propio criterio y libertad responsables, guiados por la conciencia del deber y no movidos por la coacción.

Piden igualmente la delimitación jurídica del poder público, para que la amplitud de la justa libertad tanto de la persona como de las asociaciones no se restrinja demasiado. Esta exigencia de libertad en la sociedad humana se refiere sobre todo a los bienes del espiritu bumano..."?

\section{Decisión}

Sobre la base de las trascendentales consideraciones constitucionales aludidas, en torno del respeto y promoción de los derechos humanos fundados en la dignidad de las personas, el Tribunal entra a

5 Miguel Angel Fernández Gonzáicz: "Derecho a la Vida y Derechos Fundamentales de la Persona que está por nacer" en Los Derechos de Ia Persona que está por nacer. Conferencias Santo Tomás de Aquino (Santiago, Academia de Derecho Universidad Santo Tomás, 2001) pp. $82-83$.

6 Juan de Dios Vial Larraín: Filosofia Moral (Sannizgo, Ediciones L'niversidad Carólica, 1998) pp. $1 \mid 14$ - 1 I5.

7 Dignitatis IHumanae, declaración del Concilio Varicano II sobre la libertad teligiosa, reproducida en hrtp://www, vatican, va 
examinar de lleno si el artículo $2^{\circ}$ inciso primero letra b) del proyecto respeta o no la Carta Fundamental, aun cuando, previamente, revisa el sentido y alcance de aquella norma en germen como se lee en el considerando $25^{\circ}$.

"...se observa la babilitación irrestricta que el inciso primero de la letra b) otorga al órgano administrativo correspondiente para recabar, con cualidad imperativa, toda clase de antecedentes, sin que aparezca limitación alguna que constriña tal competencia al ámbito estricto y acotado en que podría hallar justificación.

Es más, dicha habilitación se confiere sin trazar en la ley las pautas o parámetros, objetivos $y$ controlables, que garanticen que el órgano administrativo pertinente se ba circunscrito a ellos, asumiendo la responsabilidad consecuente cuando los ha transgredido.

Los razonamientos anteriores resultan también aplicables a los antecedentes secretos o reservados a que se refiere el inciso tercero de la letra b) en examen, puesto que para requerirlos, basta sólo que lo autorice el Presidente de la Corte de Apelaciones de Santiago, sin audiencia del afectado ni de terceros, tramitándose la solicitud de la autoridad administrativa en forma secreta, y debiendo aquel magistrado devolver los antecedentes del caso a ese órgano administrativo, lo que resulta absolutamente insuficiente".

Pues bien, el Tribunal Constitucional concluye, en los considerandos $26^{\circ}$ y $27^{\circ}$ :

"Que, por consigutente, la disposición en examen merece ser calificada como discrecional, es decir, abierta, por la indeterminación que contiene, con respecto a las decisiones que el Director del órgano pertinente juzgue necesario llevar a la práctica, circunstancia que reviste gravedad singular tratándose de la dignidad y de los derechos esenciales ya comentados;

Que se halla así demostrado que la dignidad de la persona y sus derechos a la vida privada y a la reserva de las comunicaciones de igual naturaleza, que fluyen de aquella, quedan en situación de ser afectados en su esencia por la normativa del proyecto examinado, sin que esta iniciativa contemple los resguardos y controles heterónomos indispensables, sobre todo los de naturaleza judicial, que eviten o rectifiquen tal eventualidad, motivos por los cuales debe ser declarada la inconstitucionalidad del artículo $2^{\circ}$ inciso primero letra b) del proyecto".

En este punto merece recordarse la prevención de los Ministros Colombo Campbell, Presidente del Tribunal, Alvarez Garcfa y Libedinsky Tschorne, los cuales no suscriben los razonamientos de la parte final del considerando $25^{\circ}$, en relación con la facultad que el proyecto otorga a la Unidad de Análisis Financiero para recabar información preventiva de antecedentes amparados por el secreto o reserva, previa autorización del Presidente de la Corte de Apelaciones de Santiago, para destinarlos posteriormente, si hubiere mérito, al Ministerio Público para que sean, finalmente, los Tribunales de Justicia los que establezcan la comisión de los delitos contemplados en el proyecto de ley:

"2०) Que, en relación a este argumento los previnientes tienen en cuenta que el Presidente de la Corte de Apelaciones de Santiago es un tribunal unipersonal reconocido por los atticulos $5^{\circ} y$ $51^{\circ}$ del Código Orgánico de Tribunales, al que el legislador orgánico, en conformidad al artículo $74^{\circ}$ de la Constitución, puede, $y$ en esta oportunidad le asigna, una nueva competencia. 
$\left.3^{\circ}\right)$ Que, igualmente tienen en cutenta que el legishador en los procedimientos nacionales, tanto en el orden civil como penal, aplicando principios informadores vastamente conocidos, ha adoptado el principio de la unilateralidad en casos excepcionales y cautelares y como una manera de asegurar la eficacia de determinadas actuaciones o resoluciones futuras y decisorias del ámbito jurisdiccional, el que puede usar sin violentar ningin precepto de la Constitución.

40) Que, en esta oportunidad los previnientes reiteran La posición contenida en Rol $N^{\circ} 349$, en orden a discrepar de la mayoría. En tal disidencia se expresó por los jueces discrepantes Colombo y Alvarez, que 'concordamos plenamente en ello cuando estamos en presencia de un proceso destinado a resolver una controversia, pero no en tanto se recurra a la jurisdicción para recabar un antecedenté como es el caso previsto por el artículo $2^{\circ}$, letra b) inciso tercero del proyecto en examen.

En otros términos, la bilateralidad es un presupuesto del proceso propiamente tal, pero no puede negársele al legislador la facultad de emplear el de la unilateralidad cuando el mérito de la norma así 10 precise, criterio que podemos encontrar aplicado en el juicio gecutivo, en las medidas prejudiciales y en diversas disposiciones cautelares del nuevo Código Procesal Penal".

Conviene, al tenor de esta prevención, detenerse, someramente, en la constitucionalidad del denominado principio de unilateralidad, vale decir, que se acceda a ciertas peticiones de una parte por el Tribunal ante el cual se solicitan sin que, previamente, se conceda al afectado el derecho a objetar lo pedido.

En este sentido, la prevención de los tres Ministros referidos, expone acertadamente que la utilización de aquel principio es constitucionalmente admisible siempre que sea empleado excepcionalmente, con carácter cautelar y para asegurar la eficacia de futuras resoluciones, pues ella constituye una alteración del principio de igualdad. Por ello, sólo se ajusta a lo preceptuado en el artículo $19^{\circ} \mathrm{N}^{\circ} 2$ y $\mathrm{N}^{\circ} 3$ de la Carta Fundamental cuando la solicitud es razonable o no discriminatoria y ello ocurre nada más que si concurren los tres requisitos copulativos referidos.

Sin embargo, en el articulo $2^{\circ}$ inciso $1^{\circ}$ letra $b$ ) del proyecto no se cumplen exactamente aquellas condiciones:

En primer lugar, la atribución conferida a la Unidad de Análisis Financiero no posee carácter excepcional, sino que goza de generalidad y permanencia, cuando lo requerido pot la Unidad son antecedentes secretos. Es decir, cada vez que se niegue, por la persona requerida, entregar la información solicitada por la Unidad de Análisis, sobre la base que ella es secreta, aquel Servicio puede acudir, sin audiencia del afectado, al Presidente de la Corte de Apelaciones para que autorice que se entregue la referida información. Con ello, queda de manifiesto el carácter permanente de la unilateralidad, cada vez que se niegue la entrega por tratarse de antecedentes secretos;

En segundo lugar, la atribución conferida por el artículo $2^{\circ}$ inciso $1^{\circ}$ letra b) no posee carácter cautelar, pues una vez entregados los antecedentes, indudablemente, no hay vuelta atrás, ya que estos resultan revelados para la Unidad, en circunstancias que lo cautelar ese esencialmente revocable; y 
En tercer lugar, el objetivo de la arribución cuestionada no es asegurar actuaciones o resoluciones judiciales futuras, pues, de hecho, nada asegura que el asunto siquiera llegue al conocimiento de los tribunales, a través del Ministerio Público, sino que el desempeño de las labores que se asignan a la Unidad.

Más aun, no puede olvidarse que, incluso tratándose del Ministerio Público -órgano autónomo y de jerarquía constitucional-, cuando una decisión suya priva, testringe o perturba el ejercicio de derechos que la Carta Fundamental asegura, debe requerir autorización judicial previa, conforme al artículo $80^{\circ} \mathrm{A}$ inciso $3^{\circ}$ de la Constitución.

Mutatis mutandi, si un servicio público -de nivel simplemente legal- ejerce una atribución que priva, restringe o perturba el derecho constitucional a la vida privada o a la inviolabilidad de las comunicaciones, puesto que ha requerido informaciones o antecedentes que son reservados, la aplicación del principio de unilateralidad se vuelve todavía más exigente, haciéndose imperativa, en todos los casos, no sólo la autorización judicial previa, sino que la obligatoria audiencia del afectado. Máxime cuando, en la disposición tachada, la intervención del tribunal persigue dotar del imperio judicial a la solicitud de acceso a información que ha sido, inicialmente, negada.

Ello, claro está, sin perjuicio de lo que se dirá al final de este comentario, en nexo con las atribuciones que, como la objetada, se han encomendado a la Unidad de Análisis, atendido que, en realidad -y las cosas en Derecho son, como reza el viejo aforismo jurfdico, lo que son y no lo que se dice que son-, la Unidad no es un servicio público cuyas funciones son de corte meramente administrativo, sino que es un ente investigativo con atribuciones propias del Ministerio Público.

En suma, de lo expuesto deviene nítido, como lo declara la sentencia -en los considerandos $18^{\circ}$ y $13^{\circ}$, a propósito de los derechos asegurados en el artículo $19^{\circ} \mathrm{N}^{\circ} 4^{\circ}$ y $\mathrm{N}^{\circ} 5^{\circ}$ de la Constitución ${ }^{8}$ - que la

8 Se lee en los considerandos aludiáos que:

"...ia Carta Fundamental asegura a todas las personas, sin discinción ni exclusión alguna, en su articuio $19^{\circ} \mathrm{N}^{\mathrm{T}} 4^{\mathrm{c}}$ inciso primero, 'El respeco y protección a la vida privada y pública y a la honm de la persona y de su familiă. En tal sentido considera esta Magistratura necesario realzar la relación sustanciah clara y direcre, gue existe entre La dignidad de ha persona, por una parte, y su proyección inmediata on la vida privada de ella y de su familia, por oura, circunstancia que vuelve indispensáble caureiar, mediante el respeto y la procección debidas, esc ámbito reservado de la vida, en el cual no es licito penetrar sin el consentirniento del afeccado, de un lado, o por decisión de ia autoriciad fundada en la ley que hubiere sido dictada con sujeción a la Constitución, de otro.

con idéntica amplieud, en el numera! $5^{\circ}$ de aquel articulo $19^{\circ} \mathrm{La}$ inviolabilidad del hogar $y$ de tada forma de comunicaciós. privada', puntualizándase que las comunicaciones y documentos privados pueden interceptarse, abrirse o registrarse en los casos y formas determinados por la ley. Nuevamente, estima esta Magistratura oportumo destacar el ligamen que existe entre La dignidad de la persana y el ejecricio de exte derecho esenciah pues $l_{\mathbf{z}}$ inviolabilidad de las comunicaciones privadas debe ser considerada una extensión, lógica $\mathrm{c}$ inevitable, sobre todo en la vida modema, del carácter personalísino o reservado que cienen ellas como base de la liberad individual y su proyección en los más divetsos aspectos de la convivencia.

Que la privacidad, en los variados rubros descritos, integra los derechos personalisimos o del patrimonio moral de cada individuo, los auties emanan de La dignidad personal, como se ha dicho, y som, por su cualidad de intimos de cada sujeto, hos más cercanos o próximos a esta caracteristica, unica y distintiza, del ser hamano. Por tal razón, ellos merecen reconocimiento y proteccion excepcionalmente categóricos tanco por la ley, como por los actos de autoridad y las conduceas de particulares o las estipulaciones celebradas entre estos;

Quc el respeto y protección de la dignidad y de los derechos a la privacidad de la vida y de las comunicaciones, son base esencial del desarrollo libre de la personatidad de cada sujeto, así como de su manifescación en la comunidad a través de los grupos incermedios autónomos con que se estructura la sociedad. En ligamen con lo que viene de ser expuesto, menester resula recordar que tal autonomia es rambién sustento del sistema de instituciones vigetre en nucstro pais, debiendo a su respecto cumplirse la exigencia de respero. especialmente cuidadoso, que se ha destacado ya con relación a la dignidad de la persona humana;

Que de gercicio del derecho a la vida privada y a la protectión de las comwnicaciones de igual naturaleza no es, obviamente, de sentido y alcance absoluto, debiendo ser reconocido, por consiguiente, que el Logislador, dencro de los limites y para las finalidades previstos en ia Constitución, especiaimente en los preceptos fundamentales de ella ya transcritos en la presente sentencia, esta habilitado en orden a 
vulneración de los derechos fundamentales es una lesión directa, al mismo tiempo, de la dignidad del titular de aquelios derechos. Pero, expandiendo el sitial de dicha cualidad en nuestro Sistema Político, del mismo modo, la violación de las garantías, mediante las cuales se instrumenta la defensa de los derechos esenciales, es igualmente un atentado de la referida dignidad.

\section{Consideraciones en Torno del Derecho a Defensa}

Con motivo del control de constitucionalidad que se ejerce respecto del artículo $8^{\circ}$ del proyecto, en virtud del cual, sin perjuicio de la responsabilidad civil o penal que pudiera corresponderles, se autoriza al Director de la Unidad para sancionar, con amonestación o multa, a las personas naturales o jurídicas que no cumplan con el deber de informar contemplado en ese artículo, o ho hagan contraviniendo lo instruido por la Unidad para tal efecto, el Tribunal formula interesantes aportes en relación con la extensión o momento para el ejercicio del derecho a la defensa.

En efecto, en los considerandos $29^{\circ}, 30^{\circ}$ y $31^{\circ}$ de la sentencia se expone, respecto de lo preceptuado en el artículo $19^{\circ} \mathrm{N}^{\circ} 3$ inciso $1^{\circ}$ de la Constitución:

"Que, en dicho precepto se consagra el principio general que impone al legislador la obligación de dictar las normas que permitan a todos quienes sean, o puedan ser afectados en el legítimo ejercicio de sus derechos fundamentales, tener la oportunidad de defenderse de los cargos que la autoridad le formule. Se desprende de lo anterior, que la voluntad del Poder Constituyente es que la ley ha de contemplar las disposiciones que resguarden el goce efectivo y seguro de tales derechos;

Que, a su vez, el articulo $19^{\circ}$ número tercero inciso segundo de la Carta Fundamental, declara que "Toda persona tiene derecho a defensa jurídica en la forma que la ley seńale y ninguna autoridad o individuo podrá impedir, restringir o perturbar la debida intervención del letrado si hubiere sido requerida...";

Que el derecho que esta última norma consagra se encuentra en relación, sustancial y directa, con aquel que contempla el inciso primero del mismo precepto, precisando el sentido y alcance de la proteción que el legislador debe prestar al ejercicio de los derechos de toda persona, refiriéndola especificamente a la defensa juridica de ellos ante la autoridad que corresponda".

Pues bien y no obstante que el artículo $8^{\circ}$ del proyecto contemplaba el derecho a recurtir de reposición ante el Director de la Unidad de Análisis y, luego, de reclamación ante la Corte de Apelaciones, el considerando $33^{\circ}$ de la sentencia va a explicar:

dictar las normas que regulen su gercicio para que sea iegitimo. Sin embargo, idénicamente claro es para esta Magiscratura que la ley no pueder, sobre la base de la habilitación consritucional recién destacada, afectar en su esencia el contenido sustancial de ese derecho, como ampoco imponeth condiciones o requistios que impidan su bibre gencicio ni privarlo de la debida tutela juridica;

Que lo razonado en el considerando precedente se aplict, con semejante vigor, al derecho asegurado en el articulo $19^{\circ} \mathrm{N}^{\circ} 5^{\circ}$ de la Constitución, pues la competencia ororgada al legislador en virud de tal disposición, concerniente a que las comunicaciones privadas pueden ser interceptadas, registradas o abieras en los casos y en la forma que sefiale la ley, debe entenderse que no permite, a través de las normas pertinentes, afecrar ní lesionas el núcleo esencial del derecho fundamental asegurado". 
"Que del análisis de las disposiciones transcritas en el considerando anterior, se desprende que no se contempla en ellas procedimiento alguno que permita al afectado una adecuada defensa de sus derechos, en sede administrativa, en forma previa a la imposición de alguna de las sanciones que el artículo $8^{\circ}$ establece".

Justificando aquella afirmación, en el considerando $34^{\circ}$ se señala:

"Que resulta evidente, por lo tanto, que el Legislador ha dejado de cumplir con la obligación que el Poder Constituyente le impone, de dictar las normas tendientes a asegurar la protección y defensa jurfdica de los derechos fundamentales de quienes se encuentren comprendidos en las situaciones que, de acuerdo con lo dispuesto en el artículo $8^{\circ}$, determinan la imposición de una sanción. Más aun, ello puede traer como consecuencia el lesionar el ejercicio de los derechos comprometidos, circunstancia que pugna con las garantias que, en los incisos primero y segundo del numeral tercero del artículo $19^{\circ}$, la Carta Fundamental consagra para resguardarlos".

Y ello, aun cuando, como se lee en el considerando $36^{\circ}$ :

"...que el propio artículo $8^{\circ}$, en su inciso tercero, señale que el afectado puede deducir recurso de reposición ante el Director de la Unidad y que, en caso que dicho recurso sea denegado, tiene la facultad de reclamar ante la Corte de Apelaciones respectiva.

Ello no altera la inconstitucionalidad de las normas en estudio, en atención a que no subsana el becho de que antes de la aplicación de la sanción por la autoridad administrativa, el afectado carece del derecho a defensa juridica que el artículo $19^{\circ} \mathrm{No}^{\circ}$, inciso segundo, en armonía con el inciso primero del mismo precepto de la Carta Fundamental, le reconocen. Este derecho a defenderse debe poder ejercerse, en plenitud, en todos y cada uno de los estadios en que se desarrolla el procedimiento, a través de los cuales se pueden ir consolidando situaciones jurídicas muchas veces irreversibles. A lo que es necesario agregar, que resulta evidente que el poder recurrir ante la Corte de Apelaciones respectiva no es suficiente para entender que, por esa circunstancia, se ha convalidado una situacion administrativa constitucionalmente objetable".

Respecto de esto último, nuevamente los Ministros Colombo Campbell, Presidente del Tribunal, Alvarez García y Libedinsky Tschorne van a exponer que no suscriben este razonamiento, atendido:

50) Que... a la Corte de Apelaciones respectiva, como tribunal ordinario que es, también se le ba conferido competencia jurisdiccional para resolver asuntos contenciosos derivados del ejencicio de la función administrativa.

60) Que el referido resorte procesal lo coloca bajo la protección jurisdiccional y, por lo tanto, no comparten el pensamiento de la mayoria en cuanto estima que resulta evidente que el poder recumir ante dicho tribunal es insuficiente para convalidar una situación administrativa constitucionaimente objetable.

$\left.7^{\circ}\right)$ Que, a mayor abundamiento, la persona sancionada podrá deducir previamente recurso de reposición, y en contra de la resolución que la deniegue apelación, cuya competencia es la que se declara insuficiente como protección constitucional por el considerando referido. En este caso la tramitación de los recursos se rigen en todo por el principio de la bilateralidad. 
8) Que, finalmente, debe tenerse en cuenta que se trata de obtener antecedentes destinados a prevenir impedir la utilización del sistema financiero y de otros sectores de la actividad económica, para la posible comisión de algunos de los delitos descritos en el artículo $20^{\circ}$ de este proyecto de ley. Si de eilos, como se dijo, surgiere alguna sospecha o indicio que amerite confrgurar alguno de los delitos antes mencionados, el servicio deberá disponer su inmediata remisión al Ministerio Pŕblico, al tenor de lo dispuesto en la parte final del artículo $2^{0}$ ".

Resulta de interés lo resuelto por el Tribunal por cuanto surge de la sentencia que, a diferencia de lo señalado por los tres Ministros que no comparten el razonamiento contenido en el considerando $36^{\circ}$, no está en juego el principio de bilateralidad, como ocurría a propósito del artículo $2^{\circ}$ letra b) del proyecto, sino que se trata del ejercicio pleno del derecho a defensa, pues la cuestión planteada estriba en dirimir si basta, para ser respetuoso de la Constitución que, frente a la sanción administrativa, se puedan deducir recursos, de reposición y ante los tribunales ordinarios, o si debe admitirse la procedencia de aquella defensa en todo el procedimiento administrativo sancionador, antes, naturalmente, que aquélla sea impuesta.

En el ámbito preciso del derecho a defensa jurídica, debe comenzarse aclarando que la extensión del derecho es amplia, en cuanto a los obligados a respetarlo, pues el no queda reducido a su ejercicio ante los tribunales, sino que tal derecho puede reclamarse de soda autoridad e incluso de los particulares que estén llevando a cabo un procedimiento que tenga por finalidad declarar el derecho aplicable. Por ello, el derecho a defensa consiste en obtener de la autoridad competente, aunque particularmente de los tribunales, La tutela efectiva de los derechos subjetivos.

Cierto es que la configuración más concreta del ejercicio de aquel derecho a la defensa constituya una materia de reserva legal, pero ello no permite sostener que el legislador pueda regularlo a su amańo, sino que debe hacerlo con respeto de lo dispuesto en el artículo $19^{\circ} \mathrm{N}^{\circ} 26^{\circ}$ de la Constitución, esto es, sin afectar la esencia del derecho o impedir su libre ejercicio.

En este contexto, no puede considerarse satisfecho el derecho de defensa estableciendo recursos, ante los Tribunales Ordinarios, de lo decidido en sede administrativa, sobre todo cuando se trata de la imposición de sanciones, sin que el afectado haya podido participar de toda la secuela procesal y ello, más todavía, sin eludir, aunque sea a título de mera teferencia, la dudosa constitucionalidad de atribuir a la Administración de potestad sancionadora:

"Que es obvio que para juzgar la constitucional idad de la ley que determine la autoridad que imponga la sanción referida en ese precepto, esa ley debe encuadrarse en las normas rectoras del Estado de Derecho, entre las que viene al caso el artículo $73^{\circ}$ de la Carta Fundamental, que, como se ha señalado, imperativamente dispone que la facultad de conocer las causas civiles y criminales, de resolverlas y de hacer ejecutar lo juzgado, pertenece exclusivamente a los tribunales establecidos por la ley.

Que el poder sancionatorio de que está investida la Administración Püblica es sólo de orden legal sin que exista ningún precepto constitucional que se lo otorgue $\mathrm{y}$, en caso alguno, puede atribuirse, ni aun a pretexto de circunstancias extraordinarias, "la facultad de conocer de las causas civiles y criminales, de resolverlas y de hacer ejecutar lo juzgado, que pertenece exclusivamen- 
te a los tribunales establecidos por la ley'. Todo acto en contravención a la exclusividad de esta facultad consagrada -como ya se ha anotado- en el artículo 73 de la Constitución Política, es nulo. Así lo dispone otro de sus preceptos -el artículo $7^{\circ}$ - constitutivo, como aquel, de las bases de la institucionalidad chilena. Las potestades generales y especiales que los artículos 24 y 32 de la Carta Fundamental otorgan al Presidente de la República no confieren -ni pueden conferir- una facultad jurisdiccional que lo invista de poder para cancelar una personalidad jurídica o disolver una corporación, las que, por la naturaleza jurisdiccional de éstas, no se comprenden entre las facultades de gobierno y administración del Poder Ejecutivo, que deben ejercerse de acuerdo con la Constitución y las leyes, como manda el citado artículo $24 \mathrm{deI}$ Código Político Nacional..."

En esta línea de pensamiento y asumiendo, como un hecho, la atribución legislativa de la potestad sancionadora a la Administración, ésta debe encuadrarse dentro de las cxigencias del debido proceso, entre las cuales se encuentra el pleno ejercicio del derecho de defensa, es decir, ejerciéndolo cabalmente durante todo el procedimiento y no sólo para recurrir en contra de una decisión ya adoptada:

"Como consignado en las actas de la Comisión de Estudio de la Nueva Constitución, 'la garantia del debido proceso legal-antes circunscrita al de naturaleza penal-se amplía a toda controversia que se promueve en el orden temporal, tribunales ordinarios, administrativos, tributarios, Contraloria General de la República, etc."'10.

Por ello, no resulta suficiente, como ya se adelantó, que, frente a una sanción impuesta por un órgano administrativo, el afectado pueda recurrir de reposición -acción normalmente de carácter simbólico, ni ante la Corte de Apelaciones, sin que haya podido desplegar, a lo largo de toda la secuela administrativa, la defensa de rigor, especialmente de frente a los hechos que han ido configurando el acto sancionado:

"...La administración debe ser consciente que es ella quien tiene la carga de la prueba de la culpabilidad de las conductas ilicitas del posible infractor. Por esta razón, no puede conformarse con levantar actas, diligencias o denuncias, sino que debe además erigirse en guardián de las fuentes de prueba que puede conseguir. Es más, la propia legislación es quien obliga a reunir cuantas más pruebas sean posibles a fin de fundamentar suficientemente la imposición de la sanción administrativa..."1].

La necesidad de aquella defensa plena, frnalmente, en el caso del artículo $8^{\circ}$ objetado, se vuelve más evidente, al adverrir que el precepto legal establecía, verdaderamente, una conducta susceptible de ser sancionada con carácter objetivo e irrebatible, ya que, bastaba que el afectado no informara o, peor aun, que no lo hiciera acatando lo instruido por la Unidad para que procediera la imposición de la

9 Consideranóos $45^{\circ}$ y $46^{\circ}$ de la sentencia pronunciada por la Corte Suprema el 16 de diciembre de 1992, reproducida en LXXXIX Retiste de Derecho y jurisprudencia 2 p. S. Sa.

10 Considerando $4^{\circ}$ de la sentencia pronunciada por la Corte de Apclaciones de Santiago el 19 de diciernbre de 199 I, confirmada por la Corte Suprema cl 24 de marto de 1992, reproducida en Rolando Pastoja Bauzá: Estatuto Administrativo Interpretado (Santiago, Ed. Jurtdica de Chile, 2000) p. 798.

1) Vicenc Aguado i Cudola: La Presunción de Certeza en el Derecho Administrativo Sancionedor (Madrid, Ed. Civitas, 1994). 
sanción. De hecho, habría sido posible sostener que al Director de la Unidad no le quedaba, de frente a aquella infracción, más que sancionar, permitténdole el precepto nada más que dirimir entre las dos alternativas de sanción allí contempladas.

Por ello, en fin, no parece tampoco atendibie la prevención del Presidente del Tribunal, Ministro Colombo Campbell, en cuanto a que sólo debia declararse inconstitucional el articulo $8^{\circ}$ del proyecto, en el caso de infracción al articulo $3^{\circ}$, pero no cuando se tratara de sancionar las infracciones a los artículos $4^{\circ}$ y $5^{\circ}$ :

"2o. ... Los articulos $4^{n}$ y $5^{\circ}$ establecen exigencias que forman parte del mérito del proyecto que crea la Unidad de Análisis Financiero, que son objetivas y que están sometidas al control jurisdiccional.

30. Que tiene además presente, que la exigencia prevista en el artículo $4^{\circ}$ pasa por una declaración previa del Servicio Nacional de Aduanas, y que el $5^{\circ}$ sólo exige que se mantengan registros por operaciones en dinero superiores a $450 \mathrm{UF}$ o su equivalente en otras monedas, por lo cual ambas situaciones son diferentes a la petición de antecedentes a los sujetos mencionados en el articulo $3^{\circ}$ del proyecto.

40. Que finalmente se reitera lo expresado en la prevención, en cuanto a que ambas situaciones son reclamables administrativamente y susceptibles de revisión jurisdiccional".

\section{Prevención del Ministro Figueroa}

Finalmente, no pueden dejar de formularse algunas reflexiones acerca de la prevención formulada por el Ministro Figueroa Yávar, quien fue de parecer de entrar, de oficio, a examinar las demás atribuciones que el artículo $2^{\circ}$ del proyecto confiere a la Unidad de Análisis Financiero, sin perjuicio que, en el considerando 44", se anticipa que:

"Los Ministros que suscriben esta sentencia estiman necesario, frente a la prevención del Ministro Juan Agustín Figueroa, dejar testimonio en el fallo, de lo dispuesto en los dos incisos finales del artículo $2^{\circ}$ del proyecto en examen. Expresan, textualmente, dichos preceptos:

'Bajo ningún respecto la Unidad de Análisis Financiero podrá ejercer competencias propias del Ministerio Público o de los Tribunales de Justicia. Asimismo, sólo podrá utilizar la información que reciba para los propósitos establecidos en esta ley, no pudiendo en caso alguno darla a conocer o entregarla a organismos o servicios distintos del Ministerio Público'.

'Cuando, del examen de los antecedentes referidos en las letras que anteceden, el Director de la Unidad de Análisis Financiero estime que aparecen indicios de que se ha cometido alguno de los delitos a que se refiere el artículo $20^{\circ}$ de esta ley, deberá disponer su inmediata remisión al Ministerio Público. Asimismo, el Ministerio Público podrá requerir a la Unidad el envio de los antecedentes que estén en su poder y que sean necesarios para las investigaciones de lavado de activos que practique, se hayan iniciado de oficio, por denuncia o por querella, cualquiera sea la fase en que ellas se encuentren". 


\section{Contenido}

No obstante lo anterior, el Ministro Figueroa Yávar sostuvo:

10. Que la preceptiva a la que recién se ha hecho referencia, se encuentra indisolublemente vinculada a aquellas normas sometidas a la fuscalización de esta Magistratura. Ello resulta patente porque todas ellas, de manera conjugada, pretenden cumplir las finalidades que el legislador expresa baber tenido en vista y, de esta manera, se refieren a una misma materia y persiguen un mismo objetivo. El criterio de extender la competencia en la forma señalada, ha sido reiteradamente mantenido por este Tribunal.

$2^{\circ}$. Que el examen de constitucionalidad que se postula en esta caso, se hace necesario porque se refiere a materias particularmente sensibles, como son los derechos y deberes constitucionales que se ligan a la creación e indagación de ilicitos penales. Ello toca al núcleo mismo de aquellos que miran a la libertad individual y la seguridad personal, a más de varios otros, algunos de los cuales han sido expresamente mencionados en este fallo.

$3^{\circ}$. Que miradas en conjunto las potestades que se entregan al brgano administrativo que se crea, no obstante lo que se declara en contrario en el inciso segundo del articulo $2^{\circ}$ de la iniciativa, lo cierto es que ellas importan encomendarle una labor de investigación de ilicitos penales, lo que nuestra Carta ha entregado, de manera exchusiva y exchuyente, al Ministerio Público, todo ello al tenor de lo prescrito en el artículo $80^{\circ} \mathrm{A}$ de aquel cuerpo, en concordancia con lo establecido en la Ley $N^{\circ}$ 19.640. En efecto, la finalidad precisa que se concede al órgano administrativo al que se le da vida, es prevenir e impedir ciertos y determinados delitos. Pero estos últimos, si bien se penan autónomamente, son técnicamente la fase de agotamiento de otros a los cuales también se hace remisión.

De esta manera, el prevenir la ocurrencia de esta última etapa del iter criminis, importa necesariamente indagar la comisión de los que la preceden, lo que cae de lleno en la actividad propia del Ministerio Público.

40. Que en un anterior pronunciamiento este Tribunal ha aceptado que la autoridad administrativa efectúe una labor de recopilación de antecedentes, aun cuando ellos se refieran a un posible ilicito penal. Pero como se desprende del sentido natural del verbo, su alcance es el de juntar lo que otros ban producido, lo que es muy distinto a una labor indagatoria activa, como es -conforme al proyecto- la de requerir declaraciones obligatorias, de todo tipo, a un gran conjunto de personas, la de ordenar exámenes periciales, la de estar revestida de potestades normativas y la de coordinar información con entes similares extranjeros. Entregar tal cúmulo de atribuciones a un ente administrativo resulta asistematico con la creación del Ministerio Público y el conjunto de regulaciones a las que éste se encuentra sometido. Su misión está estrictamente enmarcada por un conjunto de garantías para el indagado, lo que contrasta con las muy febles salvaguardas que contempla el proyecto, lo que hacía necesario un específico pronunciamiento sobre todas las facultades que se conceden a la Unidad de Análisis Financieto y a la creación misma de aquel ente investigador. 
$5^{\circ}$. Que finalmente este previniente deplora que no se bayan consultado también varias atras disposiciones contenidas en el Titulo II del proyecto, que miran a normas punitivas substanciales y procesal penales, no directamente vinculadas a las sometidas a nuestro conocimiento, pero cuyo análisis de constitucionalidad podria haber sido particularmente trascendente".

La prevención del Ministro Figueroa Yávar exige una revisión somera de la Ley $\mathrm{N}^{\circ} 19.913$, excluidas, incluso, las disposiciones que fueron declaradas inconstitucionales.

\section{Sintesis de la Ley}

El artículo $1^{\circ}$ de la Ley $N^{\circ} 19.913$ señalada, en sus incisos $1^{\circ}$ y $2^{\circ}$, crea la Unidad de Análisis Financiero, que es un servicio público descentralizado, con personalidad jurídica y pattimonio propios, que se relaciona con el Presidente de la República por medio del Ministerio de Hacienda y cuyo objeto consiste en prevenir e impedir la utilización del sistema financiero y de otros sectores de la actividad económica, para la comisión de alguno de los delitos descritos en el artículo $19^{\circ} \mathrm{de}$ la ley.

El referido articulo $19^{\circ}$ prescribe que será castigado con presidio mayor en sus grados mínimo a medio y multa de doscientas a mill unidades tributarias mensuales ${ }^{\text {"12. }}$ :

“a) EI que de cualquier forma oculte o disimule el origen ilicito de determinados bienes, a sabiendas de que provienen, directa o indirectamente, de la perpetración de hechos constitutivos de alguno de los delitos contemplados en la ley No 19.366, que sanciona el tráfico ilícito de estupefacientes y ststancias psicotrópicas; en la ley No 18.314, que determina las conductas terroristas y fija su penalidad; en el artículo $10^{\circ}$ de la ley No 17.798 , sobre control de armas; en el Título XI de la ley No 18.045, sobre mercado de valores; en el Título XVII del decreto con fuerza de ley No 3, de 1997, del Ministerio de Hacienda, Ley General de Bancos; en los Párrafos 4, 5, 6 y 9 del Tírulo V del Libro II del Código Penal y, en los artículos $141^{\circ}, 142^{\circ}$, $366^{\circ}$ quáter, $367^{\circ}$ y $367^{\circ}$ bis del Código Penal; o bien, a sabiendas de dicho origen, oculte $o$ disimule estos bienes.

b) El que adquiera, posea, tenga o use los referidos bienes, con ánimo de lucro, cuando al momento de recibirlos ha conocido su origen ilicito...".

Para alcanzar el objetivo atribuido a la Unidad de Análisis Financiero, el artículo $2^{\circ}$ establece que ella "tendrá las siguientes atribuciones y funciones, las que podrá desarrollar y ejercet en cualquier lugar del territorio nacional":

12 Sin otvidar que el articulo aclara que los que se asociaren u organizaren con el objeto de llevar a cabo algunas de las conductas deseritas en el articulo $19^{\circ}$ serán sancionados por este solo hecho, scgún las normas que alli se indican. 
“a) Solicitar, verificat, examinar y archivar la información a que se refiere el artículo $3^{\circ}$ de esta $\mathrm{ley}^{13}$.

b) Disponer exámenes periciales, los que podrá encomendar a instituciones públicas o privadas.

c) Organizar, mantener y administrar archivos y bases de datos, pudiendo integratlos, con el debido resguardo y protección, a las redes de información nacionales e internacionales para el adecuado cumplimiento de sus funciones...

g) Analizar, a to menos una vez al año, la información a que se refiere el artículo $5^{\circ}$ de esta ley ${ }^{19}$. Bajo ningún respecto la Unidad de Análisis Financiero podrá ejercer competencias propias del Ministerio Público o de los Tribunales de Justicia. Asimismo, sólo podrá utilizar la información que reciba para los propósitos establecidos en esta ley, no pudiendo en caso alguno darla a conocer o entregarla a organismos o servicios distintos del Ministerio Público.

Cuando, del examen de los antecedentes referidos en las letras que anteceden, el Director de la Unidad de Análisis Financiero estime que aparecen indicios de que se ha cometido alguno de los delitos a que se refiere el artículo 19 de esta ley, deberá disponer su inmediata remisión al Ministerio Público. Asimismo, el Ministerio Público podrá requerir a la Unidad el envío de los antecedentes que estén en su poder y que sean necesarios para las investigaciones de lavado de activos que practique, se hayan iniciado de oficio, por denuncia o por querella, cualquiera sea la fase en que ellas se encuentren".

En relación directa con el artículo $2^{\circ}$ tiene que considerarse el artículo $19^{\circ}$, en el cual se señala que

13 Dicho artículo señala:

"Las personas naturales y las personas jurtdicas que se sefialan a continuación, estarán obligadas a informar sobre los accos, transacciones u operaciones sospechosas que adviertan en el ejercicio de sus actividades: los bancos e inscituciones financieras; empresas de facroraje; empresas de arrendamiento financiero; las empresas de securitización; las administradoras generales de fondos y las administradoras de fondos de inversión; el Comité de Inversiones Extranjeras; las casas de cambio y otras entidades que estén facultadas para secibir moneda extranjera; ias emisoras y operadoras de tajjetas de crédito; las empresas de transferencia y transporte de valores y dinero; las bolsas de comercio; las corrednes de bol sa: los agentes de valores; las compafilas de segutos; los administradores de fondos mutuos; los operadores de mercados de futuro y de opciones; las representantes legales de zonas francas; los casinos, salas de juegos e hipódromos; las agentes generales de aduana; las casas de remate y martilla; las corredotes de propiedades y las empresas dedicadas a la gestión inmobiliaria; los nocarios y las conservadores.

Se cntiende por operación sespeciosa todo zcto, operación o rransacción que, de zcuerdo con los usos y costumbres de la activićad de que se trate, resulte inusuaí o carente de justificación econónica o jurtdica aparente, sea que se realice en forma aislada o reiterada. Corresponderá a la Litidad de Asáisis Financiero señalar a las enticiades a que se refiere este articulo, las situaciones que opecialmett. te habrán de considerarse como indiejarizs de operaciones o transacciones sospechosas, en sus respectivos casos.

Para los efectos de la oblización sefialada en el inciso primero de este artferlo, las personas all: indicadas deberán designar un funcionatio responsable de relacionarse con la Lnidad de Análisis Financiero.

Las disposiciones iegales, regiamentarias, contracnuales o de cualquier orm fndoie sobre secreco o reserva de dererminadas operaciones o acrividades no impedirán el cumplimiento de la obligación de informar establecida en el presente artículo. Lo anterior es también aplicable si la Unidad solicita la entrega o exhibición de los antecedentes que el sujeto obligado tuvo en consideración para reportar la operación sospechosa.

La información proporcionada de buena fe en conformidad a esta ley, eximirá de toda responsabilidad legal a quienes la entreguen".

14 Dicro articulo dispone:

"Las entidades descricas en el artfeulo $3^{\circ}$ deberán además mantener tegistros espectiales por el plazo mínimo de cinco afíos, e informar a la Linidad de Análisis Financiero cuando ésta lo requiera, àe roda operación en efecrivo superior a cuatrocientas cincuena unidades de fomento o su equivalente en orras monedas". 
Útil resulta insertar el articulo $6^{\circ}$ de la Ley $\mathrm{N}^{\circ} 19.913$ :

"Prohibese a las personas e instituciones serialadas en el artículo $3^{\circ}$, inciso primero, y a sus empleados, informar al afectado o a terceras personas, la circunstancia de haberse requerido o remitido información a La Unidad de Análisis Financiero, como asimismo, proporcionarles cuatquier otro antecedente al respecto" ${ }^{15}$.

Finalmente, el articulo $23^{\circ}$ dispone:

"La investigación de los delitos a que se refieren los artículos $19^{\circ}$ y $20^{\circ}$ de esta ley será siempre secreta para los terceros ajenos al procedimiento y también para los terceros afectados por una investigación preliminar del fiscal.

Respecto del imputado y de los demás intervinientes, la investigación será secreta cuando así lo disponga el fiscal, por un plazo máximo de seis meses, renovables con autorización del juez de garantía, por una sola vez y por igual término.

A estas investigaciones no les será aplicable lo dispuesto en el artículo $186^{\circ}$ del Código Procesal Penal, en la medida que se haya decretado su secreto en los términos señalados en el inciso precedente $^{16}$.

El que entregue o difunda información de cualquier naturaleza acerca de antecedentes de la investigación incurrirá en la pena de presidio menor en sus grados medio a máximo. Esta prohibición y sanción se extenderá a los funcionarios que hubieren participado en la investigación y a todo aquel que, de cualquier modo, informe, difunda o divulgue información relativa a una investigación e, incluso, al hecho de estarse realizando ésta".

De las disposiciones transcritas resulta nitida la finalidad perseguida al crear la Unidad de Análisis Financiero, especialmente, en lo atinente a detectar el surgimiento de bienes cuyo origen es ilicito. Para ello, la ley dota a la Unidad de importantes atribuciones que le permitan recabar, cotejar y cruzar la información que, sin ser precisada por el legislador, puede llevar a ese servicio a considerar que se está en presencia de bienes cuyo origen resulta espurio, sin que se haya constatado, de manera previa, en un debido proceso y por sentencia ejecutoriada, que aquél es el origen de los bienes.

Por ende, se está en presencia de un servicio público, dependiente del Presidente de la República, que investigará $\mathrm{el}$ origen de los bienes de personas, naturales y jurídicas, por la vía de requerirles cualquier clase de informaciones o antecedentes, para, cuando lo estime del caso, trasladar el resultado de su indagación al Ministerio Público con el objeto que se determine si se ha cometido alguno de los delitos contemplados en el artículo 19 de la Ley.

15 El articulo $7^{c}$ aciara que:

"La infracción a lo dispuesto en el articuio $6^{\circ}$ será castigada con la pena de presidio menor en sus grados medio a máximo y multa de cien a cuacrocientas unidades tributarias mensuales".

16 É referido artículo $186^{\circ}$ preceprúa que:

“Conrrol judicial antertor a la formalización de la investigación. Cualquier persona que se considerare afectada por una investigación que no se hubiere formalizado judicialtnente, podrá pedir al jue de garantía que le ordene al fiscal informar acerca de los hechos que fueren objeto de ella También podrá cl juez fijarle un plazo para que formalice la investigación ${ }^{n}$. 


\section{Se vulnera la competencia reservada constitucionalmente al Ministerio Público}

El artículo $80^{\circ} \mathrm{A}$ de la Constitución confiere, con carácter exclusivo, la función de investigar los hechos constitutivos de delito al Ministerio Público, esto es "hacer diligencias para descubrir algo" y "aclarar la conducta de ciertas personas sospechosas de actuar ilegalmente" ${ }^{\text {"17 }}$, conforme al sentido natural y obvio de las palabras. Desde luego y reiterando el artículo $80^{\circ} \mathrm{A}$ de la Carta Fundamental, no se olvide que uno de los principios básicos del Nuevo Proceso Penal consiste en aquella exclusividad de la investigación, conforme al artículo $3^{\circ}$ del Código del ramo.

De lo que se trata de dirinir, en consecuencia, para evaluar la prevención del Ministro Figueroa Yávar, es determinar si la Unidad de Análisis Financiero, a través de las atribuciones conferidas por la ley, investiga o no hechos constitutivos de delito, pues, de hacerlo, aquella atribución de potestades investigativas en lo penal adolecería de inconstitucionalidad.

Si bien el tema no fue objeto de cuestionamiento constitucional durante la tramitación del proyecto de ley ${ }^{1 \mathrm{~B}}$, resulta indudable, con la sola lectura de los artículos $I^{\circ}, 2^{\circ}$, especialmente en sus letras a), b), c) y g), y $19^{\circ}$ de la Ley $\mathrm{N}^{\circ} 19.913$, que allt se confieren a la Unidad de Análisis Financiero atribuciones que implican investigar hechos potencialmente constitutivos de delito, por cuanto no pueden leerse de manera distinta aquellas disposiciones, sin que sea óbice para ello la mera afirmación, contenida en el artículo $2^{\circ}$ inciso $2^{\circ}$ de la Ley $\mathrm{N}^{\circ} 19.913$, pues en Derecho, como ya se dijo, las cosas son lo que son, más allá de las declaraciones formales.

Desde esta perspectiva y sin perjuicio de la inconstitucionalidad en que se ha incurrido por el Legislador, en tanto ella no sea declarada -mediante el recurso de inaplicabilidad o la declaración pertjnente de oficio por la Corte Suprema, conforme al artículo $80^{\circ}$ de la Constitución-y, por ende, continúe operando la Unidad, ella debe ser respetuosa del debido proceso, conforme a lo preceptuado en el artículo $19^{\circ} \mathrm{N}^{\circ} 3^{\circ}$ inciso $5^{\circ}$ de la Constitución, ya que las investigaciones también deben acatar aquel derecho fundamental.

Con todo, el asunto, tratándose de un órgano como la Unidad de Análisis Financiero, resulta todavía más claro, pues el artículo $17^{\circ}$ de la Ley $N^{\circ}$ 19.640, Orgánica Constitucional del Ministerio Público, contempla, entre las atribuciones del Fiscal Nacional, crear unidades especializadas para colaborar con los fiscales a cargo de la investigación de determinados delitos y, en su artículo $22^{\circ}$, junto con indicar la función de aquellas unidades, señala que deberá crearse al menos una para asesorar en la dirección de la investigación de los delitos tipificados en la Ley $\mathrm{N}^{\circ}$ 19.366, que sanciona el tráfico ilícito de estupefacientes y sustancias sicotrópicas ${ }^{\text {I9 }}$.

17 Diccionario citado en supra nota 2, p. 879.

18 Véase el Infonme de la Comisión de Constitución, Legislación y justicia de la Cámata de Diputados recaldo sobre el proyecto de icy que crea la L'nidad de Análisis c Inteligenciz Financiera y modifica el Código Penal en mareria de lavado o bianqueo de activos, contenido en el Boletin de Seriones de dicha Camara, correspondiente a ia sesión celebrada el 8 de octubre de 2002; as como el informe de La Comision de Constitución, Legislacióm Jwarticia y Reghamento del Senado, segútn consta del Boletin de Sesiones de ese Corporación, corrtespondiente al 29 de abril de 2003 .

19 No se olvide que, en cumplimiento de aquella disposcíón, mediante Resolutción $\mathrm{N}^{\circ} 289$, evacuada el 18 de diciembe de 2001 por el Fiscal Nacional, se creó la Unidad Especializada en Lavado de Dinero. Delitos Económitos y Crimen Organizado. 
Pues bien, aquellas disposiciones legales no hacen sino confirmar que no sólo las atribuciones de la Unidad de Análisis Financiero, sino que ella en su conjunto, imumpe en la función constitucionalmente reservada al Ministerio Público. Y ello no implica, como podría pensarse sin reparar en la Constitución, que la Ley $\mathrm{N}^{\circ} 19.913$ está modificando la Ley $\mathrm{N}^{\circ} 19.640$, sino que ésta -Orgánica Constitucional- está explicitando las funciones constitucionales del Ministerio Público. Así las cosas, la Ley $N^{\circ} 19.913$ no modifica la Ley $\mathrm{N}^{\circ} 19.640$, sino que es, derechamente, inconstitucional.

No escapa al análisis que se viene realizando las dificultades, especialmente de carácter jurídico, que representaba para el Tribunal Constitucional haber declarado la inconstitucionalidad, prácticamente total, del proyecto que hoy es la Ley $N^{\circ} 19.913$.

En este contexto y por mencionar uno solo de los asuntos comprometidos en una decisión de esa magnitud, tiene que reflexionarse, brevemente, en torno del ámbito de competencia que posee el Tribunal Constitucional para controlat preceptos legales en germen que no han sino calificados por el Legislador como orgánico constitucionales:

"... en Chile no se ha precisado con claridad cudl es el órgano del Estado encargado de señalar $l a$ competencia que debe ejercer el órgano de control de supremacía constitucional en su carácter de preventivo, vale decir, el Tribunal Constitucional .

No es el controlado quien debe definir el área de competencia, vale decir, las materias que quedaron sometidas al contralor de constitucionalidad. No es el Congreso Nacional el que, en un oficio, le debe puntualizar al Tribunal Constitucional que se pronuncie sobre tales o cuales únicas materias, impidiéndole, si no las incluye porque no le hace llegar el texto, revisar materias que son inaceptables de ser consideradas por esa Magistratura... ${ }^{20}$.

Por lo recién expuesto, la calificación que efectúa el Congreso no es vinculante para el Tribunal, con lo cual, remitido un proyecto de ley a su control, por considerar el Legislador que incluye preceptos orgánico-constitucionales, la Magistratura Constitucional puede considerar que otros preceptos gozan del mismo carácter o, a la inversa, estimar que los así calificados no lo poseen.

Conviene recordar que, hasta 1989, el Tribunal Constitucional sostuvo que no podía extendet, de oficio, su examen obligatorio a preceptos o partes de preceptos legales que no estuvieran entre aquellos expresamente consultados por la Cámara de Origen como orgánico-constitucionales, fundándose, principalmente, en lo dispuesto por el articulo $3^{\circ}$ de la Ley $N^{\circ} 17.997^{21}$, sin advertir que dicha norma legal es aplicable sólo a los requerimientos y no a los proyectos que, conforme al artículo $82^{\circ} \mathrm{N}^{\circ} 1^{\circ}$ del Código Político, deben ser obligatoriamente revisados por el Tribunal. Sin embargo, con motivo del control que efectuó respecto del proyecto de ley que aprobaba el Código Aeronáutico, el 26 de diciernbre de 1989, los Ministros García Rodríguez y Cereceda Bravo previnieron que, no obstante concurrir a aprobar los artículos consultados:

20 José Luis Cea Egaña: “Jurisdicción Ordinaria y Jurisdicción Constirucionat” en LXI Revista dé Derecho Priblico (Santiago, Facultad de Derecho de la Lniversidad de Chile, 1998 - 1999), p. 25.

21 Dicho precepro legal, en su inciso $1^{2}$, señala que "el Tribunal sólo podrá ejercer su jurisprudencia a requerimiento de los brganos constinucionales interesdados o de las personas que intenten la acción pública en los téminos sefialados en el articulo $82^{\circ}$ de la Consricución Polírica". 
"... fueron de parecer de entrar al análisis de otras normas contenidas en ell, a fin de emitir pronunciamiento sobre la totalidad de la normativa sometida a su conocimiento y ejercer asi el 'control de la constitucionalidad de las leyes' que tienen el carácter de orgánicas constitucionales, mandato imperativo que le impone el $N^{\circ} 1^{\circ}$ del artículo 82 de la Constitución Política de la República...

Que la atribución que se otorga al Tribunal Constitucional por el referido número $1^{\circ}$ del artículo 82 de la Constitución procede ser ejercida, en concepto de los previnientes, de diferente modo que las otras que el mismo artículo establece en sus números $2^{\circ}$ a $12^{\circ}$, para dar así cabal cumplimiento a sus facultades, las que de otro modo quedarán subordinadas al arbitrio del poder cuyo control encomienda la ley al Tribunal Constitucional...

Que de lo señalado se desprende que, a diferencia de los requerimientos exigidos en los casos aludidos, en el caso del número $I^{\circ}$ recae directamente sobre el Tribunal la obligación de examinar los proyectos de leyes que tengan el carácter de orgánicos constitucionales y de los que interpreten algún precepto de la Constitución, y que lleguen a su conocimiento en virtud del cumplimiento del deber que le impone el artículo 82 en su inciso tercero a la Cámara de origen de enviar al Tribunal Constitucional el proyecto respectivo;

Que de esta manera, no procede que el Tribunal Constitucional se restrinja en el control que la Constitución Política le encarga ejercer, por el hecho de que el Poder Legislativo le indique que lo consulta sólo con respecto a ciertas y determinadas disposiciones del proyecto que le envía" 22 .

La posición minoritaria recién transcrita, sin embargo, va a conformarse con la mayoría, v. gr., en la sentencia pronunciada el 22 de noviembre de 1963, aun cuando sea en una situación específica consistente en haberse consultado incisos determinados de un artículo del proyecto:

"Que no obstante que la Camara de origen sometió a control como materia propia de ley orgánica constitucional conforme al artículo $82, \mathrm{~N}^{\circ} 1^{\circ}$, de la Constitución, los incisos décimo y décimo primero del articulo $13 \mathrm{~A}$; los incisos quinto, sexto y séptimo del articulo 15; los incisos tercero y cuarto del artículo $36 \mathrm{~A}$, y el inciso primero del artículo 39, todos del proyecto de ley en análisis, este Tribunal estima, tal como lo ha seńalado precedentemente, que los incisos que se han sometido a su control constituyen un solo todo organico y sistemático con los restantes incisos, que forman parte del artículo que los contiene, y que con un análisis parcializado de su contenido no puede desarrollar en su integridad y cabalmente su labor fundamental destinada a la preservación de uno de los valores rectores que conforman las Bases de la Institucionalidad contenidas en nuestra Carta Fundamental, cual es velar por el principio de la supremacía constitucional a que se refieren sus artículos $6^{\circ}$ y $7^{\circ}$.

El Tribunal Constitucional cumple su función de control de constitucionalidad que la Carta Fundamental le señala en el artículo $82, \mathrm{~N}^{0} 1^{\circ}$, confrontando la disposíción orgánica constitucional consultada con la correspondiente norma de nuestra Constitución que le daría tal 
carácter, pero, d Tribunal no puede verse restringido en el ejercicio de su labor al consultársele solamente incisos de un articulo, en especial si éste constituye una disposición nueva que se crea, pues tal como se ha señalado, los incisos o partes de un artículo forman un solo todo que es jurídicamente dificil de separar y permiten al sentenciador constitucional comprender su exacto contenido y alcance ${ }^{23}$.

La decisión adoptada por el Tribunal, reiterada más tarde en otros pronunciamientos, como los contenidos en los Roles $\mathrm{N}^{\circ} 180,184$ y 186 :

“...provocó hacia el Tribunal una fuerte crítica política, pues por primera vez el Tribunal había entrado a conocer de materias no consultadas por la Cámara de Origen.

Esta discrepancia a nivel institucional entre ótganos del Estado sobre dispares opiniones, promovió que los presidentes de las Cámaras y de las Comisiones de Constitución y Legislación y los Ministros del Tribunal adoptaran un acuerdo extraoficial, que si bien no es vinculante se ha mantenido en líneas generales vigente.

Este acuerdo consiste básicamente en que:

1. Si la Cámara de Origen consulta sólo incisos el Tribunal controlará todo el artículo.

2. Si hay remisión de un artículo consultado a otro no consultado se conocerá también el articulo remitido.

3. Si no se consulta un artículo que viene a modificar o derogar una disposición anteriormente controlada se entiende que el Tribunal queda facultado para conocerla"24.

Así aparece, por ejemplo, de lo resuelto el $1^{\circ}$ de febrero de 1995 :

"Que, el artículo 530 del Código Orgánico de Tribunales, que se modifica por el $\mathrm{N}^{\circ} 14$, del artículo $1^{\circ}$, del proyecto remitido fue objeto de un pronunciamiento de este Tribunal en el Rol $N^{\circ}$ 62, pot sentencia de 9 de enero de 1989 , oportunidad en que lo declaró como norma propia de ley orgánica constitucional. De acuerdo a lo señalado precedentemente, este Tribunal estima que, en consecuencia, debe pronunciarse sobre la modificación antes aludida, porque ella tiene, según lo expresado, el carácter de orgánica constitucional;

Que, el inciso cuarto del artículo 782, del Código de Procedimiento Civil, sometido a conocimiento de este Tribunal, contempla una norma que se refiere a la petición que puede formularse si se ha interpuesto un recurso de casación en el fondo, con el objeto de que éste sea conocido por el pleno de la Corte Suprema, de conformidad a lo establecido en el artículo 780 del mismo cuerpo legal. Esta última disposición es la que establece en propiedad el denecho que tienen las partes en tal sentido, y determina la oportunidad y forma en que ellas lo pueden hacer valer.

De esta manera, tal como anteriormente lo ha expresado este Tribunal, para cumplir en la forma debida con su función de velar por la supremacia constitucional, no puede limitarse a

24 Manuel José Benitez Gibbons y Marfa de la Luz Méndez Montes: El Control de lo Orgánico Conssitucionalen la Constitución de 1980 (Memotia de Grado, Sanriago, Facultad de Derecho de la Universidad de Chile, 2003), pp. 146 - 147. 
analizar parcialmente la primera de dichas disposiciones, sino que también la segunda, que es a la que aquella se remite, que por su propia naturaleza tiene también carácter orgánico constitucional. Por lo demás, si se observan en conjunto ambos preceptos, resulta evidente que están tan estrechamente vinculados que el examen de uno conlleva necesariamente al del otro, no sólo porque los dos regulan jurf́dicamente el ejercicio de una misma facultad, sino que, además, porque el inciso cuarto del artículo 782 del Código de Procedimiento Civil, tiene como fundamento precisamente el artículo 780 del mismo cuerpo legal" 25.

En consecuencia, una vez que el Legislador ha decidido remitir un proyecto de ley, en conformidad al artículo $82^{\circ} \mathrm{N}^{\circ} 1^{\circ}$ de la Carta Fundamental, por considerar que incluye preceptos orgánico-constitucionales, queda abierta la competencia del Tribunal Constitucional para desestimar aquella calificación o para incorporar a su examen otras disposiciones no consideradas así en el iter legislativo, pues es la Constitución, en su texto y contexto, la que determina lo orgánico-constitucional y no el Legislador, correspondiéndole al Tribunal Constitucional interpretarla, en cuanto supremo garante de la Carta Fundamental. En la especie, en este sentido, no resulta aplicable el artículo $3^{c}$ de la Ley $\mathrm{N}^{\circ} 17.997$ que sólo persigue acotar el ámbito de los requerimientos, pero que no opera en el caso de control obligatorio de constitucionalidad.

Ciertamente y en el ámbito de lege ferenda, hay que advertir que debe perfeccionarse el procedimiento actualmente vigente, ya que no puede quedar entregada al Legislador la determinación, sin control o revisión de especie alguna, de si envía o no un proyecto al Tribunal, pues, como ocurrió con el Código Procesal Penal, puede adoptar la decisión de que no contiene normas orgánico-constitucionales y omitir su remisión, evitándose así el examen preventivo. Urge, por ejemplo, conceder acción popular en esta materia.

\section{Aplicación del Precedente}

Por último, conviene destacar que, en la sentencia que se está comentando, el Tribunal Constitucional funda dos de sus decisiones en jurisprudencia que ya ba pronunciado con anterioridad. Así, las inconstiucionalidades que declara respecto de los artículos $8^{\circ}$ y $2^{\circ}$ inciso $1^{\circ}$ letra $j$ ), son coincidentes, como lo recuerda el considerando $38^{\circ}$, con lo que ya habia resuelto el Tribunal Constitucional en su sentencia pronunciada el 17 de junio de 2003, en relación con el proyecto de ley sobre transparencia, límite y control del gasto electoral, Ro! No 376 .

Asimismo en el considerando $39^{\circ}$, el Tribunal trae a la memoria:

"Que, de acuerdo a lo resuelto por esta Magistratura en la sentencia de 28 de julio de 1998 , autos Rol $\mathrm{N}^{\circ} 276$, declarado por el Tribunal que un determinado articulo de un proyecto es inconstitucional, igualmente lo son aquellas normas del mismo que se encuentren tan ligadas con aquél, que por sí solas carezcan de sentido, se tormen inoperantes $o$, dada la íntima conexión entre sí, se pueda presumir razonablemente que los órganos colegisladores no las hubieren aprobado". 
Con base en este último razonamiento, la sentencia analizada señala, en sus considerandos $40^{\circ}$ y $41^{\circ}$ :

"Que en la situación juridica anteriormente precisada, están las disposiciones del texto en examen que hacen referencia al artículo $2^{\circ}$ letra b) que se declarará inconstitucional, por cuanto ellas, por sí mismas, sin la debida correlación con la norma aludida, no tienen significación alguna, es decir, como lo expresa la sentencia aludida, 'carecen de sentido', o se apartan de la voluntad legislativa con la cual fueron aprobadas, como acontece con la parte primera de la letra g) del articulo $2^{\circ}$, después de la inconstitucionalidad que afectará a su oración final".

En lo expuesto resulta necesario detenerse, aunque sea para formular una breve constatación, consistente en que, si bien siempre el Tribunal Constitucional ha acudido a su jurisprudencia para fundar sus decisiones, en el último tiempo resulta evidente La intención de reforzar este recurso al precedente. Se da lugar así a una sana y correcta práctica, pues contribuye, obviamente, a la seguridad juridica y a la confianza en esa Alta Magistratura: a la vez que ayuda a la conciencia constitucional ${ }^{26}$ y a la constitucionalización del Derecho. Ello, en fin, irá formando doctrina más sólida, en torno del sentido y alcance de la Carta Fundamental, lo cual permitirá acudir a la jurisprudencia como antecedente, no sólo ante el Tribunal Constitucional, sino ante ottos órganos estatales, especialmente para invocarla en causas concretas ante los Tribunales Ordinarios. Se visualiza allí, en fin, la asunción del rol de garante máximo de la Constitución.

Como contrapartida, en todo caso, y con el objetivo de alcanzar los valores recién enunciados, el Tribunal debe tener en consideración que, cuando una decisión resulte contraria a los precedentes, también deberá fundamentarlo, exponiendo las razones, de índole variada, que lo llevan a modificar su jurisprudencia, sobre todo, en resguardo de la igualdad ante la ley. 